\title{
SENSIBLE TEMPERATURE AT THE ŁEBA SANDBAR (SŁOWIŃSKI NATIONAL PARK) ON SELECTED DAYS OF THE 2010 SUMMER SEASON
}

\author{
Marek PóŁrolniczaK \\ Adam Mickiewicz University, Institute of Physical Geography and Environmental Planning, Department \\ of Climatology, Poznań, Poland
}

Manuscript received: May 19, 2011

Revised version: September 3, 2011

PóŁrolniczaK, M., Sensible temperature at the Łeba Sandbar (Słowiński National Park) on selected days of the 2010 summer season. Quaestiones Geographicae 30(3), Bogucki Wydawnictwo Naukowe, Poznań, pp. 83-99, 31 Figs., 2 Tabs. ISBN 978-83-62662-75-3. ISSN 0137-477X. DOI 10.2478/v10117-011-0029-6

АвSTRACT. The analysis was performed on the basis of weather measurements conducted in the Słowiński National Park at the Łeba Sandbar in the period from 8th July to 6th August 2010. Two biometeorological indices were calculated: the effective temperature (ET) and the radiative-effective temperature (RET). The daily course of RET was used to select the typical days, which were then subjected to a detailed analysis. This consisted in assessing the influence of individual meteorological elements and the synoptic situation on the development of the values of the RET and ET indices. A considerable diversity of sensible conditions was determined, as well as the considerable variability thereof during the day, in particular during the movement of atmospheric fronts. The sensible conditions were also influenced by factors connected with local circulation and the presence of the sea. Finally, a considerable decrease in the values of RET and ET was observed during changes in wind direction, namely when the wind was blowing from the northern sector.

KEYWORDS: radiative-effective temperature, effective temperature, Łeba Sandbar

Marek Pótrolniczak, Institute of Physical Geography and Environmental Planning, Poznań, Adam Mickiewicz University, ul. Dzięgielowa 27, 61-680 Poznan, Poland, e-mail: marekpol@amu.edu.pl

\section{Introduction}

Issues connected with human thermal sensibility constitute the basic aspect of an assessment of bioclimatic conditions. For this reason, researchers have for many years been looking for an index that would satisfactorily reflect the actual sensibility of thermal conditions. The significance of this issue is further confirmed by the proposal for adopting, for the purposes of recreation and tourism, a weighted assessment of individual cli- mate features, for which 0.6 is recognised as the thermal component, 0.3 as the visual (aesthetic) component, and 0.1 as the physical state of the atmosphere (De Freitas 2003).

Łeba, being a tourist resort that also aspires to the status of a spa, is in particular need of a thorough and reliable analysis of biothermal conditions, especially during the summer period. Since this region is viewed as an area with pristine nature and clean water and air, the specificity of the local climate may constitute an additional factor 
of the geographic environment, favourably or negatively impacting the opportunities for tourism, holiday rest and spa treatment. Another, equally important cognitive aspect in the case of Łeba is the analysis of local conditions in the specific dune area of the Słowiński National Park.

Research into sensible thermal conditions in Poland using biometeorological indices has been conducted since the nineteen sixties. Works that focused on analyses of the effective temperature (ET) and the radiative-effective temperature (RET) include studies devoted to geographical regions, e.g. the Baltic coastline (Leśko, Gregorczuk 1968), the entire country (Gregorczuk, Leśko 1970; Krawczyk 1991), and even individual townships, among others Krynica Morska (Marciniak 1974) and Iwonicz Zdrój (Krawczyk 1975).

The objective of the present study is an analysis of meteorological elements and synoptic situations determining the sensible conditions in the summer period along the Baltic coastline in the area of the Łeba Sandbar.

\section{Materials and methods}

The author made use of the results of weather measurements carried out between 8th July and 6th August 2010 at the Field Station of the Climatology Unit of the Adam Mickiewicz University. The station is located on the Łeba Sandbar in the Słowiński National Park, approximately 10 kilometres west of Łeba. Measurements were performed using the MAWS automatic weather station, which during the research period was situated approximately 30 metres from the sea, on the so-called grey dune. This is a flat area behind the strip of sand dunes (white dune), covered with lichen and low-growing grass, which together comprise a plant community known as Helichryso-Jasionetum (Bednorz, Kolendowicz 2010).

The analysis of sensible conditions was based on two biometeorological indices from the group of so-called quasi-temperatures: the effective temperature (ET) and the radiative-effective temperature (RET). The effective temperature is an index that reflects the total impact of temperature, air humidity and wind speed on the development of thermal conditions felt by a fully-clothed man, and by one stripped to the waist, in both instances standing in shade - because calculations of the effective temperature do not take into consideration solar radiation. In turn, the radiative-effective temperature - apart from elements required to determine the effective temperature additionally takes into consideration the intensity of total solar radiation. Such an approach makes possible the broader application of this index also for assessing the thermal sensibility of a person standing on open land. For assessing sensible thermal conditions, use was made of Mikhailov's scale, which takes into consideration the thermal sensibility of a man performing light work and dressed in so-called regular clothes (thermal insulation of $1 \mathrm{clo}$, equal to thermal resistance of $0.155 \mathrm{~K}^{*} \mathrm{~m} / \mathrm{W}^{2}$ ). According to this scale, successive ranges of ET and RET correspond to the following thermal sensibility: ET/RET $\left({ }^{\circ} \mathrm{C}\right)<1.0-$ very cold; 1.0-8.9 - cold; 9.0-16.9 - cool; 17.0-20.9 - refreshing; 21.0-22.9 - comfortable; 23.0-26.9 warm; $\geq 27.0$ - hot.

The sensibility ranges for thermal conditions described as refreshing and comfortable are considered most favourable for man (KozłowskaSzczęsna et al. 1997). In turn, the categories of warm and hot are connected with warm discomfort, while the categories of cool, cold and very cold - with cold discomfort.

The analysis takes into consideration values at 12 UTC, and also values for the whole day taken at hourly intervals. Hourly values were used as the basis for analysing the daily course of thermal sensibility, while the hour of noon was selected since it is considered as representative of bioclimatic studies, which is connected with the time of day in which the greatest human physical activity occurs (Baranowska et al. 1986; KozłowskaSzczęsna et al. 1997).

In order to calculate ET and RET, use was made of the BioKlima $\bigcirc$ programme, version 2.6 (www.igipz.pan.pl/geoekoklimat/blaz/bioklima.htm), developed by Błażejczyk, with the following input data: air temperature, relative humidity, total intensity of solar radiation, and wind speed. Due to the fact that the anemometer was located at a height of 4 metres above ground level, for successive calculations it was necessary to reduce the wind speed to 2 metres. Use was made of the formula previously applied in the 
works of Krawczyk (1991), Kozłowska-Szczęsna et al (1997), and of Błażejczyk (2004):

$$
\mathrm{v}_{\mathrm{z}}=\mathrm{v}_{\mathrm{w}}\left(\mathrm{h}_{\mathrm{z}} / \mathrm{h}_{\mathrm{w}}\right)^{0.2}
$$

where: $v_{z}-$ is the wind speed at a height of $z$ $(\mathrm{m} / \mathrm{s}) ; \mathrm{v}_{\mathrm{w}}$ - is the wind speed at the height of the anemometer $(\mathrm{m} / \mathrm{s}) ; \mathrm{h}_{\mathrm{z}}$ - is the researched height $\mathrm{z}$ $(\mathrm{m}) ; \mathrm{h}_{\mathrm{w}}-$ is the height of the anemometer $(\mathrm{m})$.

\section{Research results}

The objective of the study was an analysis of biothermal conditions, and thus first of all we presented the basic meteorological elements that determine thermal sensibility, i.e. air temperature, wind speed, air humidity and the intensity of solar radiation.

The average daily temperature in the researched period amounted to $20.3^{\circ} \mathrm{C}$, i.e. it was considerably higher than the average values for July and August $\left(17.0^{\circ} \mathrm{C}\right.$ and $16.9^{\circ} \mathrm{C}$ respectively) which were given for the years 1986-2005 for the station in Łeba by Baranowski (2008). In turn, at 12.00 noon the average temperature reached $23.0^{\circ} \mathrm{C}$. The highest average daily temperature values were observed at the beginning of the researched period. Between the 10th and 13th day of July they exceeded $24^{\circ} \mathrm{C}$, with the highest average daily temperature $\left(27.9^{\circ} \mathrm{C}\right)$ being noted on 11th July (Table 1). The highest tempera- tures amongst daily maximums, and also from amongst those measured at 12.00 noon (Fig. 1), also occurred in this period. The greatest absolute temperature value for the researched period was noted on 11 th July at $15.00\left(35.6^{\circ} \mathrm{C}\right)$. In turn, the lowest temperature $\left(10.8^{\circ} \mathrm{C}\right)$ occurred on 20 th July at 4.00 .

An important factor impacting human perception of thermal conditions is wind. In the event of high air temperatures, high wind speeds constitute a favourable biometeorological element that leads to a reduction of heat stress. On the other hand, under low temperature conditions, the action of wind is connected with the unfavourable enhancement of cold stress. During the researched days, the wind conditions were relatively diverse. The average wind speed for the analysed period amounted to $1.8 \mathrm{~m} / \mathrm{s}$. The highest average daily wind speed was noted on 25 th July $(4.8 \mathrm{~m} / \mathrm{s})$, and the lowest $(0.6 \mathrm{~m} / \mathrm{s})$ on 2 nd August (Table 1). The wind speed in individual measurement hours changed from complete silence, which was noted on numerous occasions, to $10 \mathrm{~m} / \mathrm{s}$ on 25 th July at 1.00 , while the average wind speed for 12.00 was 2.3 m/s (Fig. 2).

Another significant meteorological element impacting the thermal sensibility of atmospheric conditions is air humidity. Considerable air humidity in conjunction with high air temperature leads to a feeling of sultriness, while in low temperatures it compounds the feeling of coolness. In

Table 1 . The daily values of air temperature $(\mathrm{t})$, wind speed $(\mathrm{v})$, water vapour pressure (e) and average daily total solar radiation (Kglob) in Łeba during the period from 8th July to 6th August.

\begin{tabular}{|c|c|c|c|c|c|c|c|c|c|}
\hline dzień & $\mathbf{t}$ & $\mathbf{v}$ & $\mathbf{e}$ & Kglob & dzień & $\mathbf{t}$ & $\mathbf{v}$ & $\mathbf{e}$ & Kglob \\
\hline 08. VII & 18.6 & 2.2 & 15.6 & 469.2 & 23 & 20.4 & 2.6 & 21.4 & 83.1 \\
\hline 09 & 20.2 & 1.2 & 17.1 & 408.8 & 24 & 20.9 & 2.6 & 22.9 & 48.4 \\
\hline 10 & 24.7 & 1.2 & 18.1 & 444.6 & 25 & 14.7 & 4.8 & 14.8 & 75.1 \\
\hline 11 & 27.9 & 0.8 & 18.9 & 440.1 & 26 & 16.5 & 2.0 & 14.8 & 240.2 \\
\hline 12 & 27.0 & 1.3 & 20.1 & 443.5 & 27 & 16.4 & 1.2 & 15.5 & 181.9 \\
\hline 13 & 25.2 & 1.3 & 20.3 & 332.5 & 28 & 16.1 & 2.6 & 16.5 & 68.5 \\
\hline 14 & 21.4 & 1.7 & 20.3 & 453.9 & 29 & 16.5 & 2.8 & 16.9 & 138.2 \\
\hline 15 & 21.7 & 1.5 & 20.8 & 398.0 & 30 & 17.3 & 1.5 & 15.0 & 357.0 \\
\hline 16 & 22.5 & 1.6 & 19.2 & 404.1 & 31 & 17.5 & 1.1 & 15.5 & 411.0 \\
\hline 17 & 23.4 & 1.3 & 22.3 & 319.5 & $1 . V I I I$ & 20.8 & 0.7 & 15.9 & 242.4 \\
\hline 18 & 20.2 & 3.8 & 18.2 & 225.4 & 02 & 19.5 & 0.6 & 18.1 & 170.9 \\
\hline 19 & 19.9 & 2.5 & 14.6 & 435.4 & 03 & 17.3 & 1.9 & 18.7 & 47.4 \\
\hline 20 & 19.0 & 1.6 & 15.0 & 434.8 & 04 & 18.1 & 2.6 & 16.1 & 283.3 \\
\hline 21 & 24.8 & 1.5 & 17.1 & 391.9 & 05 & 18.6 & 1.1 & 16.2 & 287.0 \\
\hline 22 & 25.1 & 1.3 & 22.1 & 405.8 & 06 & 18.2 & 1.7 & 18.7 & 267.4 \\
\hline
\end{tabular}


both instances, high air humidity is unfavourable for the human body. During the researched period, the pressure of water vapour attained an average daily value of $17.9 \mathrm{hPa}$. The same average value was observed at 12.00 . From amongst the average daily values of water vapour pressure, the lowest amounted to $14.6 \mathrm{hPa}$ (19th July), and the highest $22.9 \mathrm{hPa}$ (24th July). The maximum value of water vapour pressure was noted on 22nd July at 13.00 $(24.4 \mathrm{hPa})$, and the minimal value $(12.2 \mathrm{hPa})$ two days previously at 3.00 (Fig. 3).

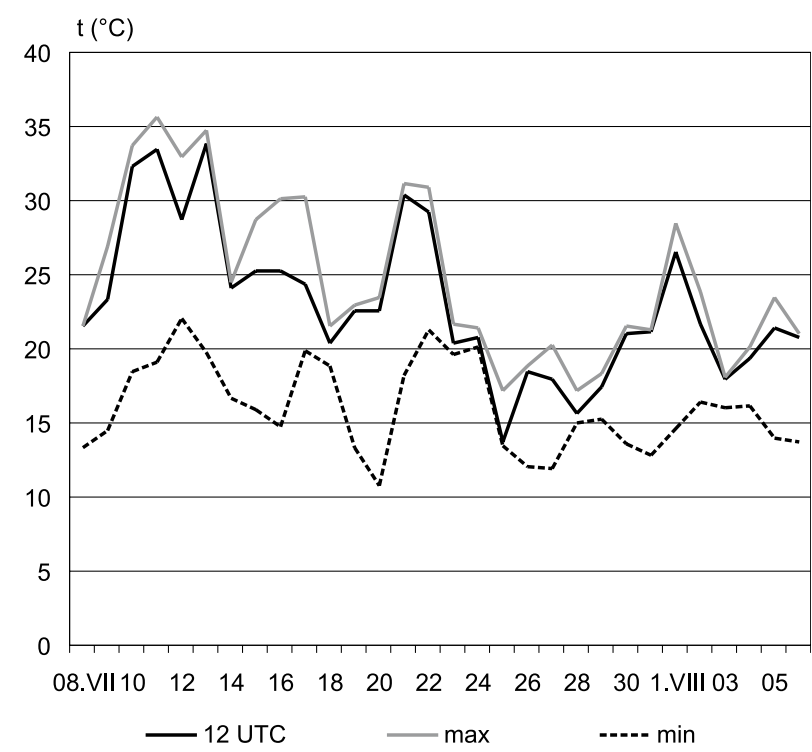

Fig. 1. Air temperature $\left({ }^{\circ} \mathrm{C}\right)$ at the Łeba Sandbar during the period from 8th July to 6th August 2010.

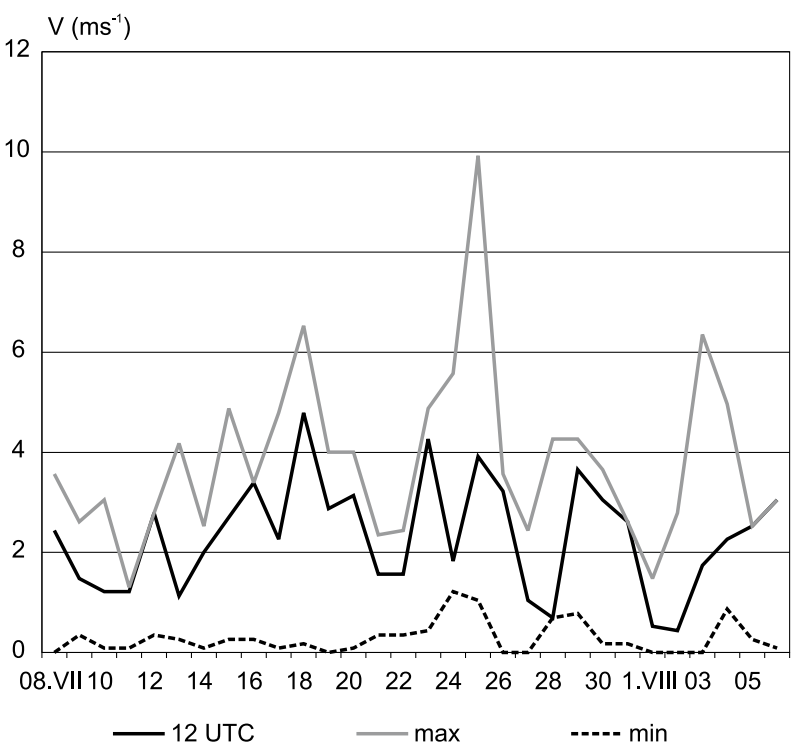

Fig. 2. Wind speed $\left(\mathrm{ms}^{-1}\right)$ at the Łeba Sandbar during the period from 8th July to 6th August 2010.
An analysis of the values of total radiation during the researched days has made it possible to discern a considerable differentiation in the influx of solar energy (Fig. 4). From the beginning of the researched period until 22nd July there were days with very high values of total radiation, which is shown by the average daily values, at 12.00 , and also by the maximum daily values. From 23rd July, the values of solar radiation point to a lesser share thereof during the day, and also to a greater variability from day to day.

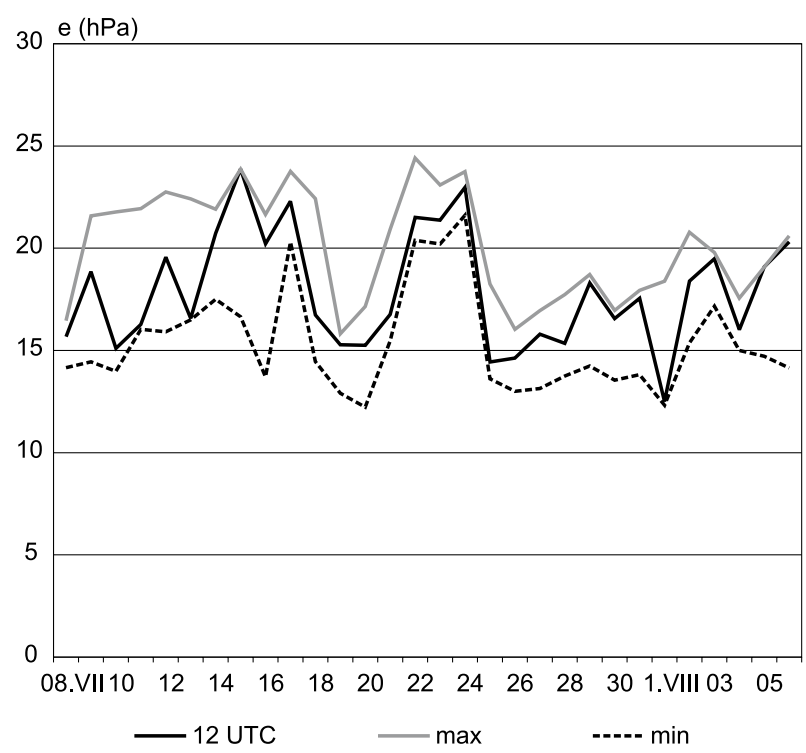

Fig. 3. Water vapour pressure (hPa) at the Łeba Sandbar during the period from 8th July to 6th August 2010.

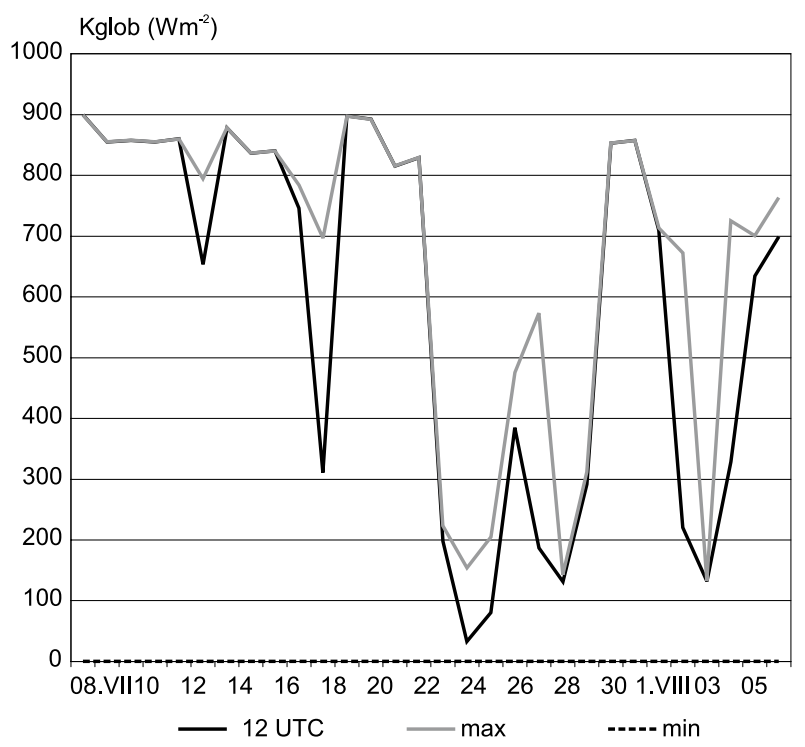

Fig. 4. Total radiation $\left(\mathrm{Wm}^{2}\right)$ at the Łeba Sandbar during the period from 8th July to 6th August 2010. 
The average daily value of total radiation during the researched period amounted to 297.0 $\mathrm{Wm}^{-2}$. On individual days, average values ranging from $47.4 \mathrm{Wm}^{-2}$ (3rd August) to $469.2 \mathrm{Wm}^{-2}$ (8th July) were noted. In turn, at 12.00 the average for the entire researched period totalled 592.4 $\mathrm{Wm}^{-2}$, with extreme values ranging from 32.7 $\mathrm{Wm}^{-2}$ to $899.8 \mathrm{Wm}^{-2}$ (Fig. 4).

\section{Sensible conditions determined on the basis of the effective temperature (ET) and the radiative-effective temperature (RET)}

Over the analysed period, sensible conditions were noted in six out of the seven ranges of the adopted scale (Mikhailov's). Not a single day occurred with conditions that could be described as very cold. On the basis of values of the effective temperature (ET) and the radiative-effective temperature (RET) at $12 \mathrm{UTC}$, one may state that conditions termed as "cool" were the most frequent. According to the ET index, 16 such instances were noted, whereas according to the RET index, their number was considerably smaller - only 9 (Table 2). Considerable discrepancies between the number of days satisfying the criteria for the aforementioned indices also occurred for the hot category, under which 6 days of the researched period were classified; however, according to the ET, no such day occurred. As regards the other ranges of the Mikhailov's scale, similar numbers of days were noted. For the cold range, a single day was observed under both indices, while in the very cold range - none.

During the first few days of the researched period, sensible conditions according to ET were classifiable as refreshing, comfortable, warm and very warm. In this period, the human body was usually subjected to the effects of heat stress (Fig. 5). In turn, from 18th July conditions connected with cold stress were predominant. Most frequently, they were felt as cool, and only in single instances as cold, comfortable and refreshing. However, according to the RET, in the first period the conditions noted were connected with the ranges of warm and hot (Fig. 6). According to this index, the

Table 2. The number of days with an effective temperature (ET) and radiative-effective temperature (RET) according to the Mikhailov's scale at 12 UTC in Łeba in the period from 8th July until 6th August 2010.

\begin{tabular}{|c|c|c|c|c|c|c|c|}
\hline & hot & warm & comfortable & refreshing & cool & cold & very cold \\
\hline ET & 0 & 5 & 2 & 6 & 16 & 1 & 0 \\
\hline RET & 6 & 6 & 3 & 5 & 9 & 1 & 0 \\
\hline
\end{tabular}

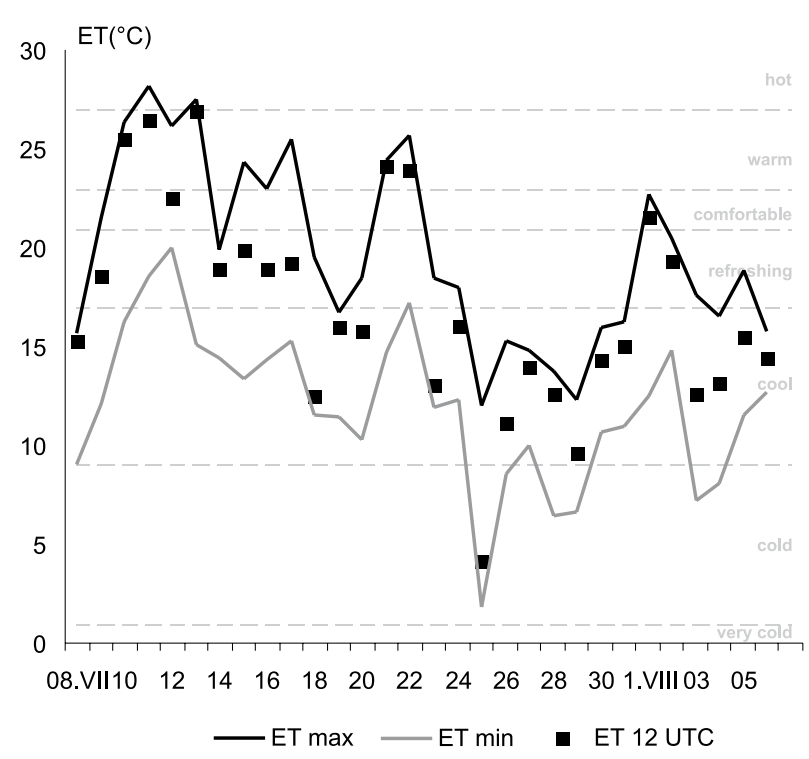

Fig. 5. Effective temperature $\left({ }^{\circ} \mathrm{C}\right)$ at the Łeba Sandbar during the period from 8th July to 6th August 2010.

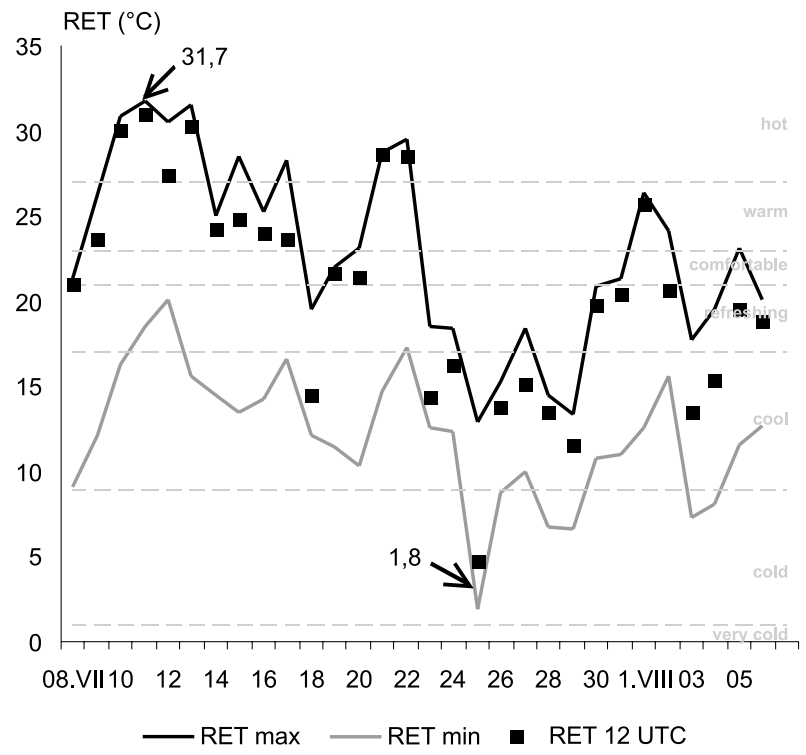

Fig. 6. Radiative-effective temperature RET $\left({ }^{\circ} \mathrm{C}\right)$ at the Łeba Sandbar during the period from 8th July to 6th August 2010. 
discomfort connected with heat stress was very much more evident during this period. In addition, high air humidity was noted on these days, in many cases leading to a feeling of sultriness (Fig. 3). During the days of 18th-22nd July, highly variable sensible conditions occurred, from cool through comfortable to hot, while over the next few days, until 29th July, a feeling of coolness was predominant, however with a single instance of conditions described as cold. Over the next few days (from 30th July to 6th August), the radiative-effective temperature noted usually indicated refreshing conditions, with "coolness" being noted only in two instances, and "warmness" in one. The maximum RET and ET values occurred on $11^{\text {th }}$ July at 15.00 , amounting to $31.7^{\circ} \mathrm{C}$ and $28.2^{\circ} \mathrm{C}$ respectively, while the minimum values were noted on 25th July at 4.00 (the value was $1.8^{\circ} \mathrm{C}$ in both cases).

For further analysis, the author selected typical days on which thermal conditions corresponding to individual ranges of the adopted Mikhailov's scale were felt, or such during which sensible conditions changed considerably over the 24-hour period. The daily changes in the ET and RET values were shown and an attempt was made at analysing the basic weather elements and synoptic conditions affecting sensible temperatures.

\section{Day with sensible thermal conditions classified as "hot" (11th July)}

On this day - according to RET - the sensible temperature attained values from the hot range (Fig. 7). At 12 UTC, the RET values were in the same range, and for this reason in bioclimatic studies this day shall be classified as hot. However, it was a warm day according to the ET values, even though in later hours sensible temperatures classified as hot were noted. In the remaining hours, the sensible thermal conditions of the day did not fall below refreshing. This range was noted simultaneously for ET and RET from the beginning of the day until the early morning hours. At 6.00, RET entered the range of comfortable due to the significant influx of solar radiation at this time. During the hours 7.00-8.00 (RET) and 8.0013.00 (ET), the sensible temperature was warm, while from 9.00 to 19.00 (RET) and from 14.00 to 19.00 (ET) it was hot.

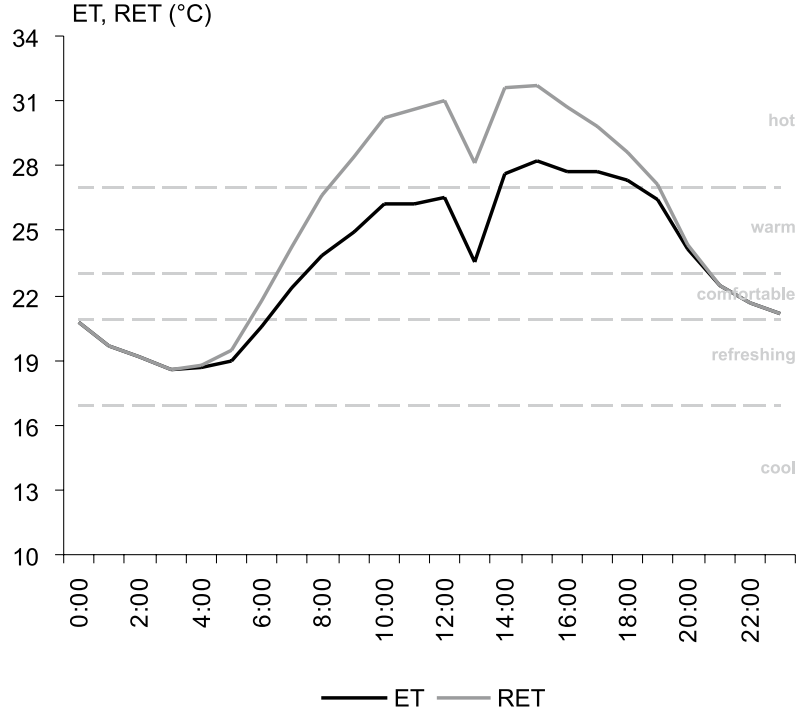

Fig. 7. Course of the daily effective temperature (ET) and radiative-effective temperature (RET) in Łeba on 11th July 2010.

Such a course of sensible temperatures was considerably impacted by the influx of solar radiation during the day, as a result of which the air temperature rose quickly from the early hours to a maximum value of $35.6^{\circ} \mathrm{C}$ at 15.00 (Fig. 8.). This was the highest air temperature noted during the entire researched period. What is more, 11th July was the warmest day of all those researched. The air temperature during that day did not fall below $19.1^{\circ} \mathrm{C}$, noted at 3.00 .

During this day, at 13.00 a considerable fall in the values of ET and RET was observed, this being caused by a fall in air temperature (by $4.6^{\circ} \mathrm{C}$ in comparison with the temperature recorded at 12.00) with an unchanged wind speed and slightly greater influx of total radiation (at 14.00, the air temperature had already risen to $35.0^{\circ} \mathrm{C}$, i.e. it was $6.2^{\circ} \mathrm{C}$ higher than an hour previously). This was accompanied by an increase in water vapour pressure. An analysis of data concerning the wind direction shows that such a considerable change in air temperature and in sensible temperature over such a short time was caused by a wind blowing from the sea, from a northeasterly direction, which brought with it cooler and more humid air; previously, the wind had blown primarily from the southern sector. This situation very clearly demonstrates the impact of a large body of water on local sensible conditions. For an equivalent temperature, the thermal 

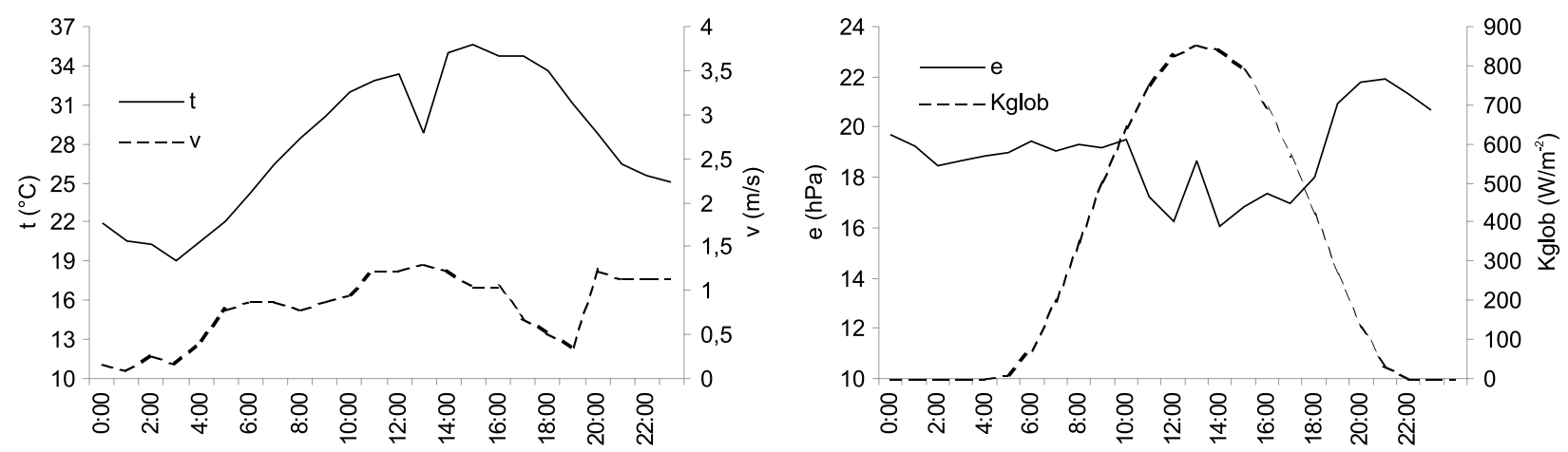

Fig. 8. Daily course of air temperature (t), wind speed (v), water vapour pressure (e) and total solar radiation (Kglob) in Łeba on 11th July 2010.

feeling of warm was at this time reduced to a level close to the thermal comfort and subsequently, when the wind returned to a southerly direction, it shifted to the feeling of hot. The sensible conditions remained at this level until 18.00, whereafter they changed to warm and comfortable (both ET and RET simultaneously) at 23.00. It should also be noted that throughout the day the sensible temperature was only slightly affected by wind force, as its maximum values noted just exceeded $1 \mathrm{~m} / \mathrm{s}$.

The daily course of individual meteorological elements, as well as of sensible temperature modified by local conditions, was determined by the synoptic situation existing over Central and Eastern Europe. On 11th July, Poland was under the influence of a vast high, with its centre over Lithuania, in hot, tropical air coming from Africa and settling over western and northern Poland. Only the south-eastern parts of the country remained under the influence of a somewhat cooler mass of air. In the majority of the country, the weather was very hot (Fig. 9). Satellite photographs show cloudless skies over the entire territory of Poland, and cells of storm clouds near the western border, along the cool atmospheric front. This same front is visible on the synoptic map, which shows the situation existing over western France just a few hours earlier. Łeba enjoyed cloudless, high-pressure weather throughout the entire day.

Masses of tropical air reach Poland very infrequently, and thus it is worth taking a closer look at the mechanism governing their movement. In this case, tropical air had been moving from above Africa for a number of days, and its continued transport above Europe was made possible by the existing baric situation. Initially, a shallow low occurred above western Africa, which caused the movement of a mass of tropical air over Western Europe, while in successive days the high with its centre over Central and

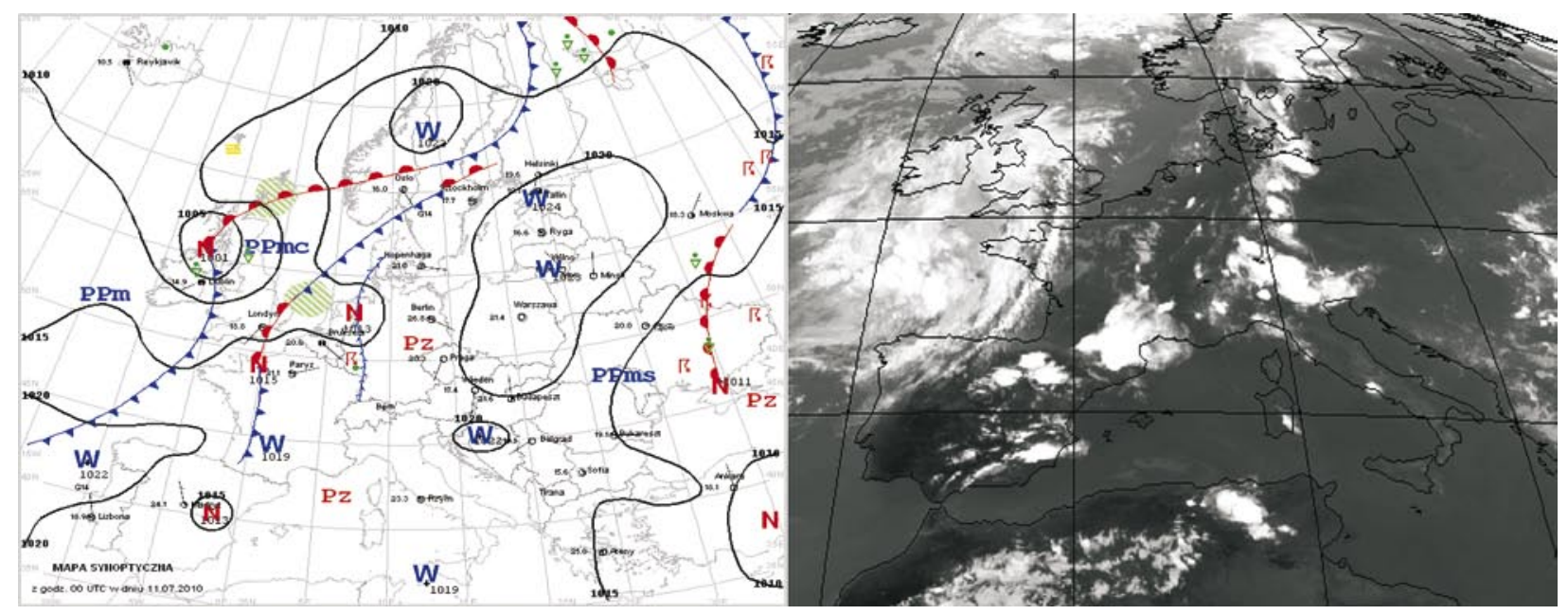

Fig. 9. Satellite photograph MSG2 (IR 0.8 at 18 UTC) and synoptic map (at 00 UTC) on 11th July 2010. 

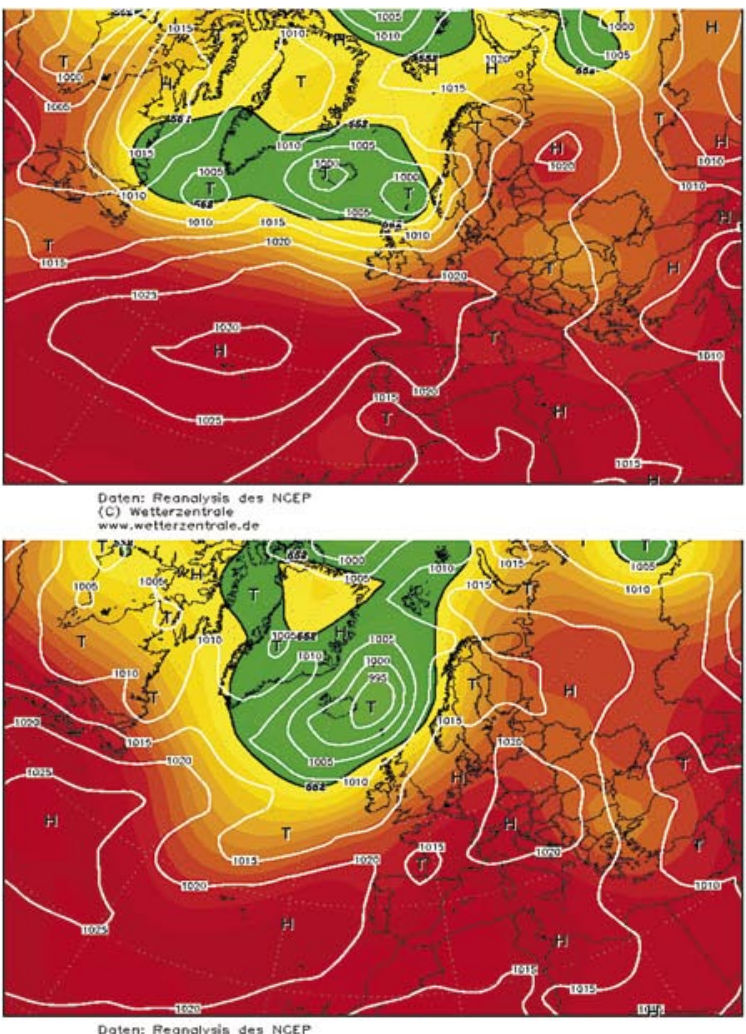

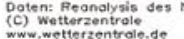

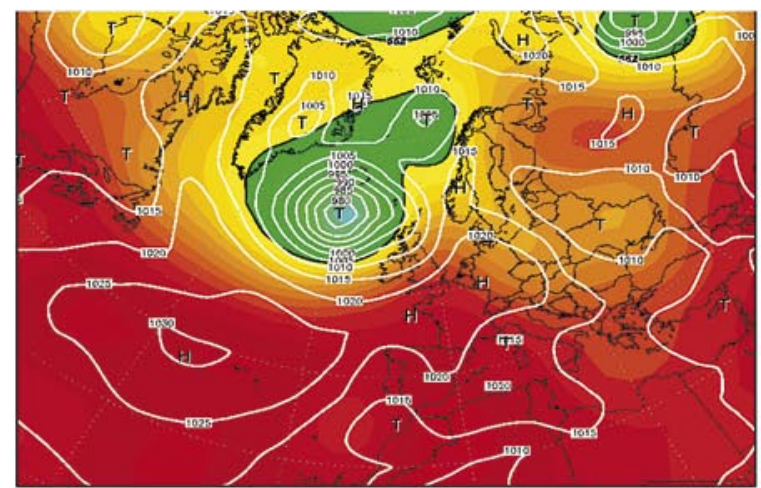

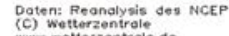

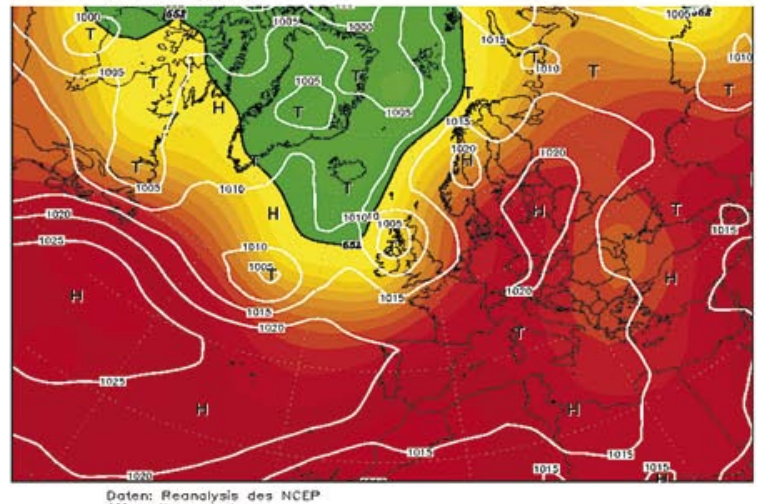

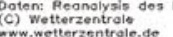

Fig. 10. Sequence of geopotential maps and pressure fields on 5th, 7th, 9th and 11th July 2010.

Southern Europe directed it towards Poland. The mechanism of transfer of the mass of tropical air has been shown by the sequence of geopotential maps from the NCEP reanalysis (Fig. 10).

\section{The day of 13th July in the hot (RET) range,} with a considerable change in sensible temperature throughout the day

On this day (as on 11th July) at 12 UTC the radiative-effective temperature indicated a value from the hot range. However, this day was distinguished by a different course of daily sensible temperatures (Fig. 11). From daybreak, both ET and RET pointed towards refreshing conditions, while from the early morning hours these conditions began to shift to the ranges of comfortable and warm. From 9.00 to 13.00 , the RET value indicated hot thermal sensibility. After 13.00, the sensible conditions began to alter rapidly, reaching a feeling of coolness as early as 16.00 . In successive hours, both ET and RET increased to refreshing, and subsequently fell to the cool range.

On this day, sensible temperatures were affected by the large values of total solar radiation, which attained a maximum at a level slightly in excess of $800 \mathrm{~W} / \mathrm{m}^{-2}$ (Fig. 12). On this day, the air temperature started to rise rapidly from the early morning, attaining its maximum value of $34.7^{\circ} \mathrm{C}$ at 13.00. Following this, the temperature fell considerably to $22.7^{\circ} \mathrm{C}$, noted at 15.00 . In successive

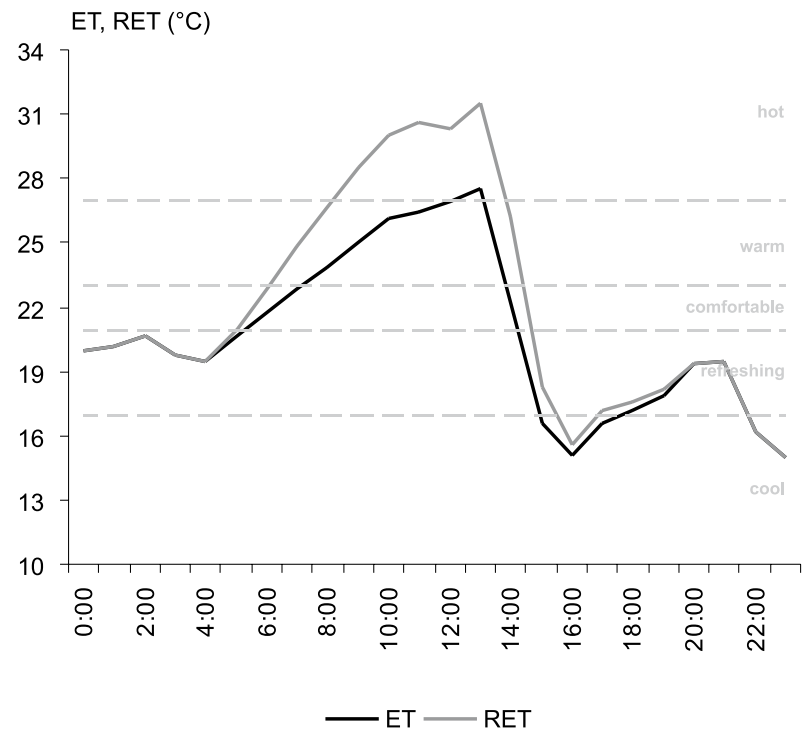

Fig. 11. Course of the daily effective temperature (ET) and radiative-effective temperature (RET) in Łeba on 13th July 2010. 

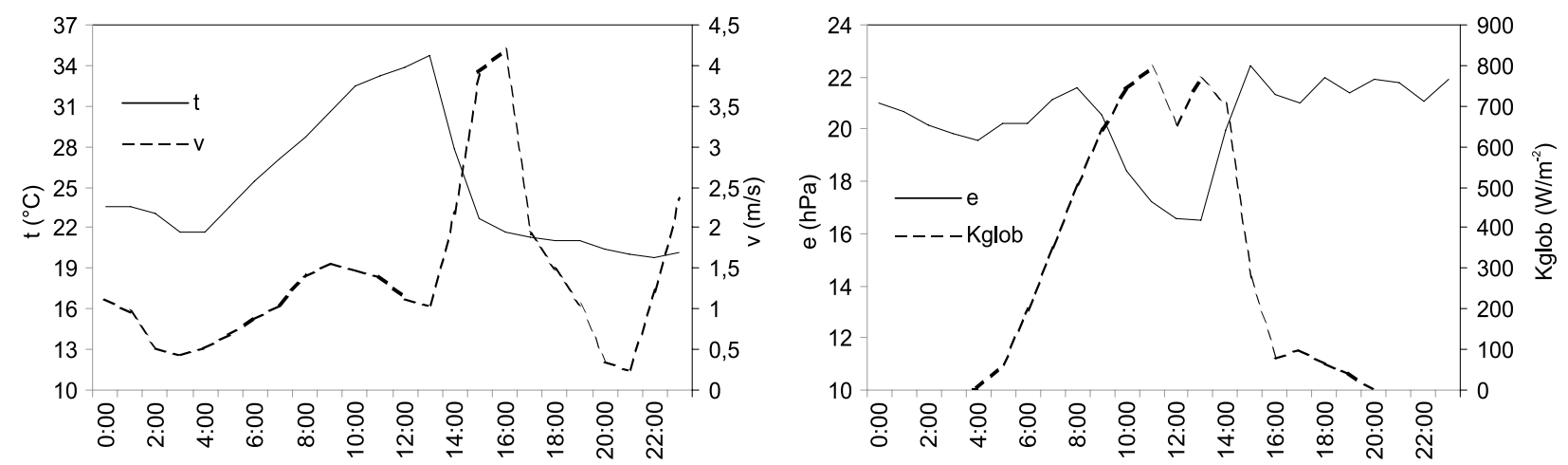

Fig. 12. Daily course of air temperature (t), wind speed (v), water vapour pressure (e) and total solar radiation (Kglob) in Łeba on 13th July 2010.

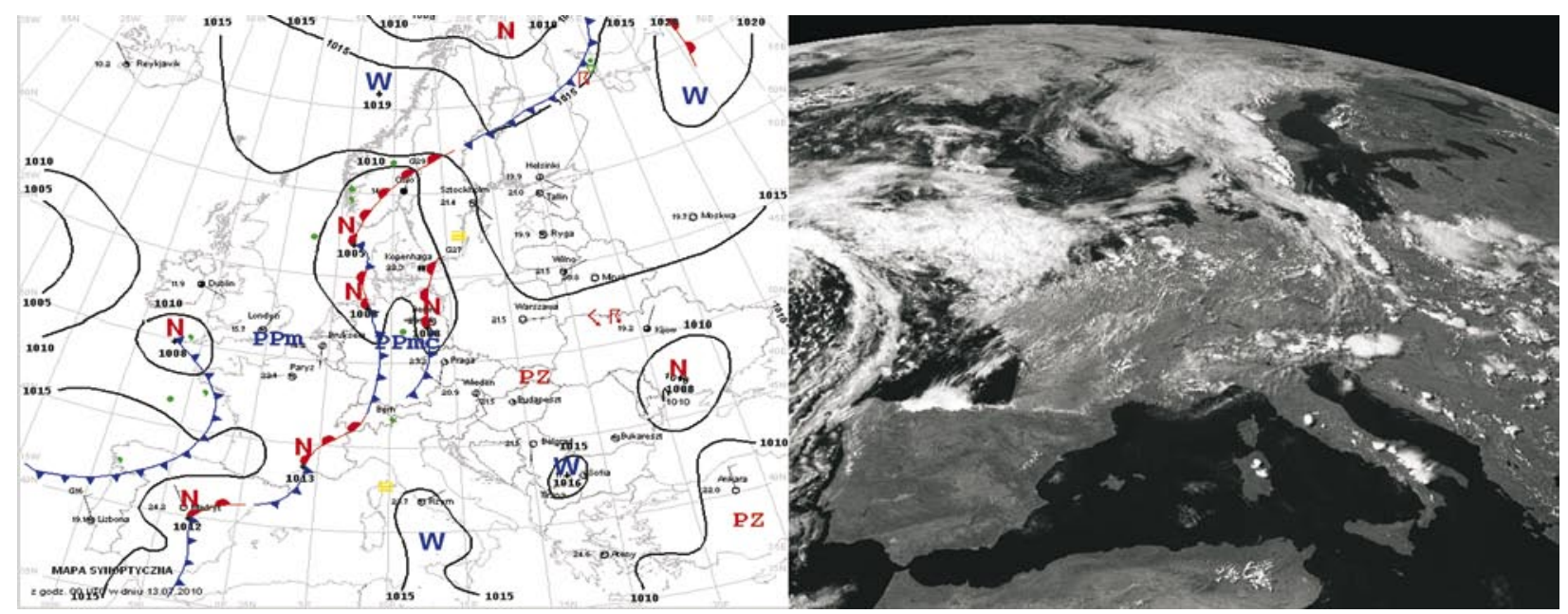

Fig. 13. Satellite photograph MSG2 (vis. at 15.12 UTC) and synoptic map (at 0.00 UTC), taken on 13th July 2010.

hours, the air temperature remained at the level recorded at 15.00 .

A significant element determining the sensible conditions on this day was the wind speed. During the first half of the day, wind speeds attained low values, with a maximum of $1.5 \mathrm{~m} / \mathrm{s}$ at about 9.00. From 14.00, however, the wind speed rose considerably and at 16.00 UTC it exceeded $4 \mathrm{~m} / \mathrm{s}$. In successive hours of this day, the wind speed once again fell to the previously noted value, i.e. under $0.5 \mathrm{~m} / \mathrm{s}$, at about 21.00 . On the other hand, the humidity of air remained at a high level of approximately $21 \mathrm{hPa}$ nearly throughout the day, with the exception of a period between 12.00 and 14.00 , when the water vapour pressure attained a minimal value of some $16 \mathrm{hPa}$.

The daily course of sensible temperature and weather elements discussed above was determined by the synoptic situation shown in Fig. 13. On this day, as on 11th July, Poland continued to be under the influence of a mass of tropical air, however a cold atmospheric front - followed by cooler and more humid polar-maritime air, was already drawing near from the west. A satellite photograph taken at 15.12 shows the same cool front proceeding over Poland (Fig. 13). It was the action of this front, with the clouds and numerous storm cloud cells clearly visible on the photograph, and the replacement of tropical air with polar-maritime air following its passage, that evidently impacted the weather conditions in Łeba. The increase in wind speed and air humidity, as well as the fall in air temperature (Fig. 12), was responsible in this instance for a considerable fall in sensible temperature (Fig. 11).

\section{Day with sensible thermal conditions classified as "comfortable" (20th July)}

On 20th July between 9.00 and 13.00, the thermal conditions sensible to man as "comfortable" according to RET were noted (Fig. 14). In the morning and afternoon, RET indicated refresh- 


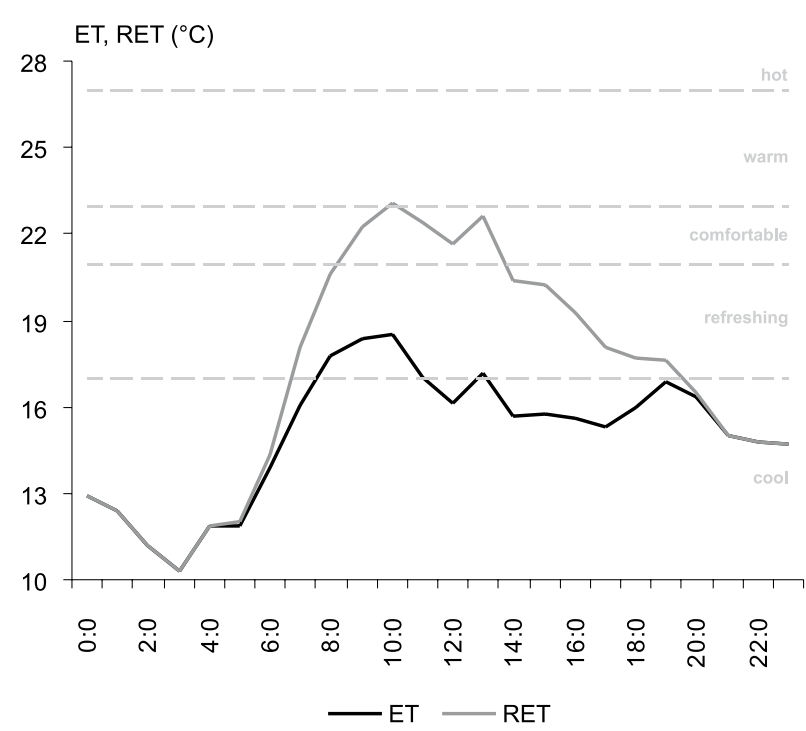

Fig. 14. Course of the daily effective temperature (ET) and radiative-effective temperature (RET) in Łeba on 20th July 2010.

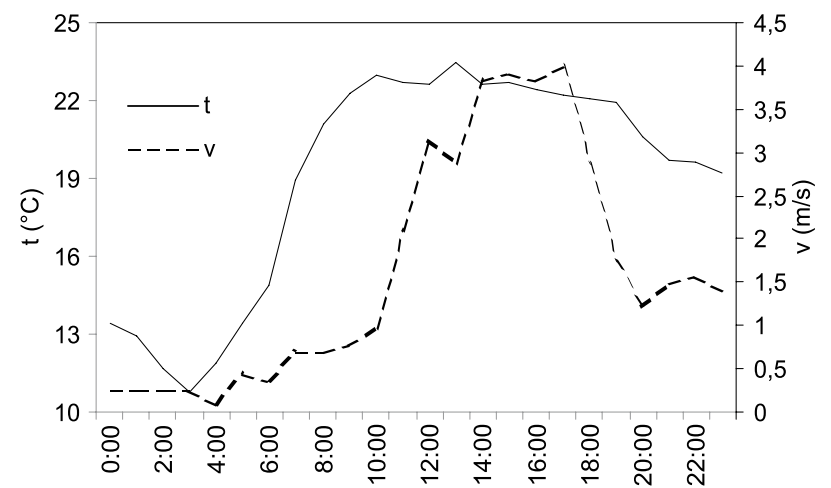

ing conditions, and cool in other parts of the day. ET, in turn, showed considerably lower values, attaining during the day a maximum sensible range of refreshing, however with the most frequent being cool. On the basis of the daily RET course we may state that in the first part of the day sensible conditions very rapidly attained the level of comfortable, which was then maintained for a few hours, whereas in the second part of the day the value of RET gradually fell.

When analysing the selected weather elements, we may state that the day in question was characterised by a large influx of solar radiation (maximum of approximately $900 \mathrm{~W} / \mathrm{m}^{2}$ ), as a result of which the air temperature rose very rapidly from the morning, attaining a daily maximum of $23.5^{\circ} \mathrm{C}$ at 13.00 (Fig. 15). In the afternoon, the temperature maintained a rather high level (approx. $22^{\circ} \mathrm{C}$ ), and this did not alter until 19.00. Subsequently, the temperature fell, however in

Fig. 15. Daily course of air temperature (t), wind speed (v), water vapour pressure (e) and total solar radiation (Kglob) in Łeba on 20th July 2010.

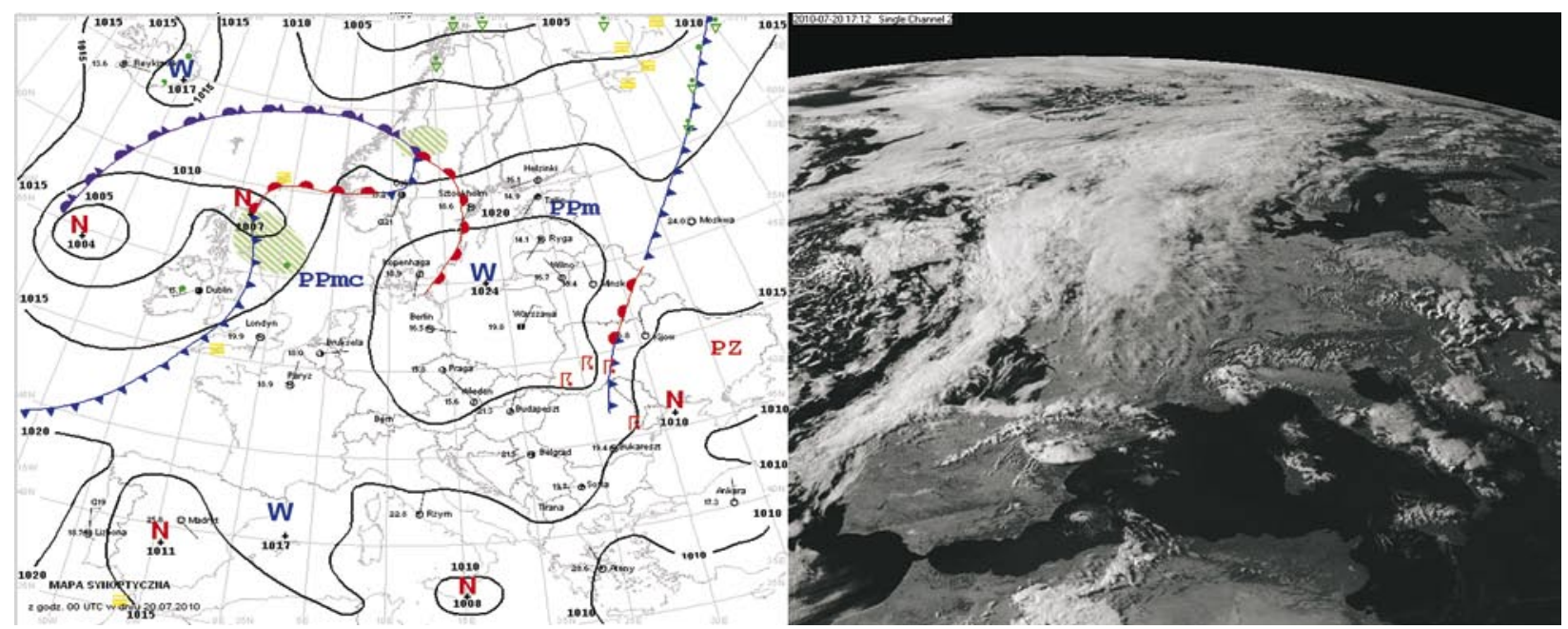

Fig. 16. Satellite photograph MSG2 (vis. at 15.12 UTC) and synoptic map (at 0.00 UTC), taken on 20th July 2010. 
successive hours it continued to have relatively high values at a level of some $19^{\circ} \mathrm{C}$, which were noted until 23.00. An important element affecting thermal sensibility on this day was the wind speed. At the beginning of the day it was low (resulting in the comfortable conditions), but as early as at 11.00 it amounted to some $2 \mathrm{~m} / \mathrm{s}$, while between 12 and 18 it exceeded $3 \mathrm{~m} / \mathrm{s}$. Maximum wind speeds of $4 \mathrm{~m} / \mathrm{s}$ were noted at 17.00. At this time, the increase in wind speed accompanied by a nearly constant air temperature caused a fall in the value of sensible temperature (ET, RET). The previously felt comfortable (RET) and refreshing (ET) conditions changed into refreshing and cool, respectively (Fig. 14).

On this day, the weather was determined by a receding high from the centre, which was moving from the southern Baltic towards Latvia (Fig. 16). A cooler mass of polar-maritime air was present over Poland, and this was gradually heated throughout the day. Initially, the northern part of the country was sunny, whereas later the clouds were small and moderate, which is why the air temperature on this day initially rose rapidly, and in the afternoon, in the evening and at night it remained at a relatively high level. A satellite photograph taken at 15.12 shows the development of layered clouds, which in subsequent hours extended to cover northern Poland (Fig. 16).

\section{Day with sensible thermal conditions classified as "cool" (23rd July)}

The 23rd of July was one of the coldest days in the researched period. The sensible temperature (ET and RET) was cool nearly throughout the day, and only at two moments - at 2.00 and 3.00

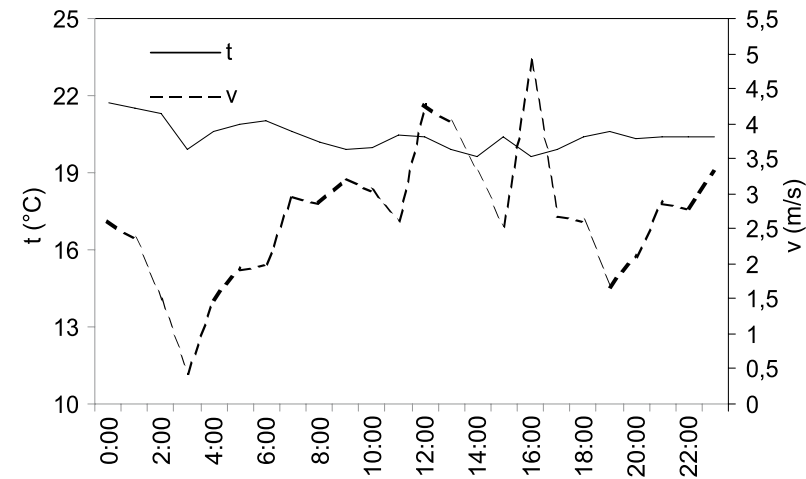

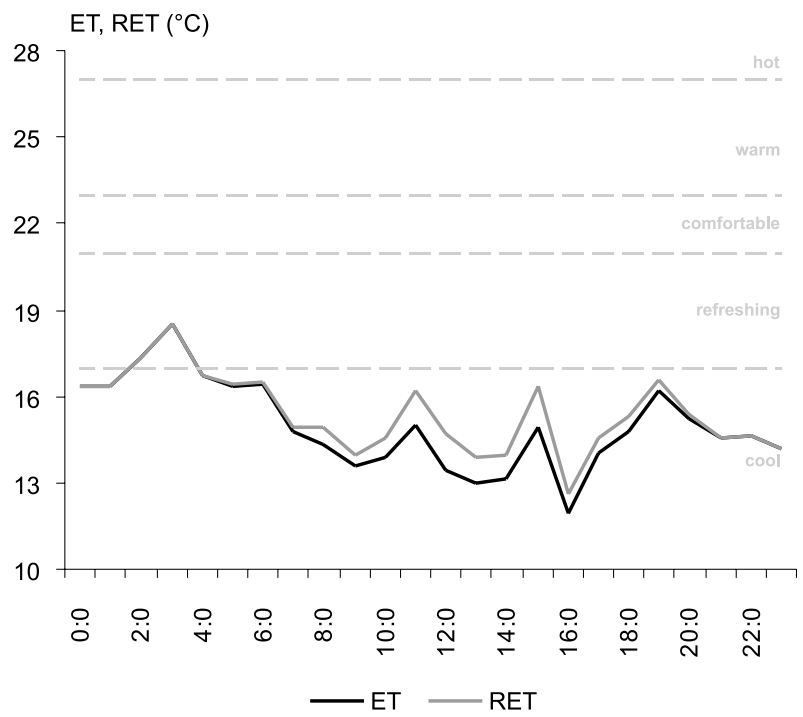

Fig. 17. Course of the daily effective temperature (ET) and radiative-effective temperature (RET) in Łeba on 23rd July 2010.

- did it attain the refreshing range (Fig. 17). The daily course of both indices showed relatively small changes from hour to hour until 10.00 and after 17.00. Greater fluctuations of these values occurred in the remaining period. Both indices indicated nearly the same or identical values throughout the day.

On this day, the dominant factors determining the sensible conditions were the wind and total solar radiation (Fig. 18). Throughout the day a relatively small influx of solar radiation was noted, and for this reason the air temperature attained no more than some $20^{\circ} \mathrm{C}$, which remained stable over the 24-hour period. The high temperature values in the night-time and early morning $(0.00-8.00)$ were caused by the presence of tropical air. The average daily wind speed totalled nearly $3 \mathrm{~m} / \mathrm{s}$, with the maximum being nearly 5

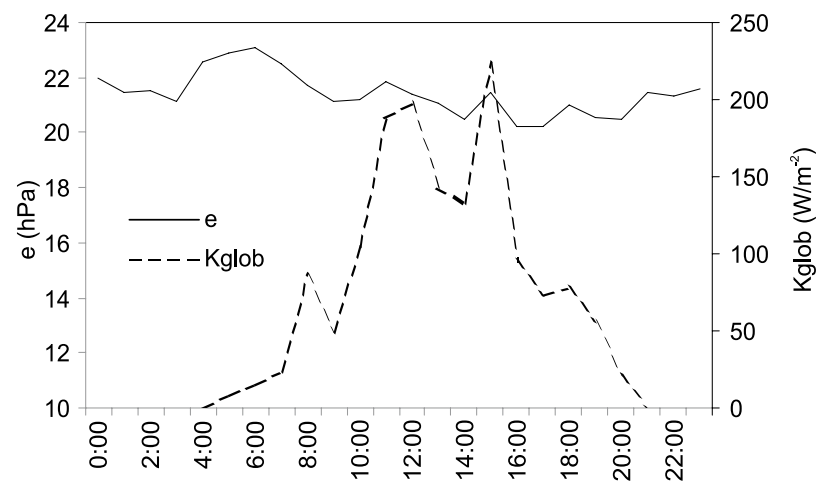

Fig. 18. Daily course of air temperature (t), wind speed (v), water vapour pressure (e) and total solar radiation (Kglob) in Łeba on 23rd July 2010. 


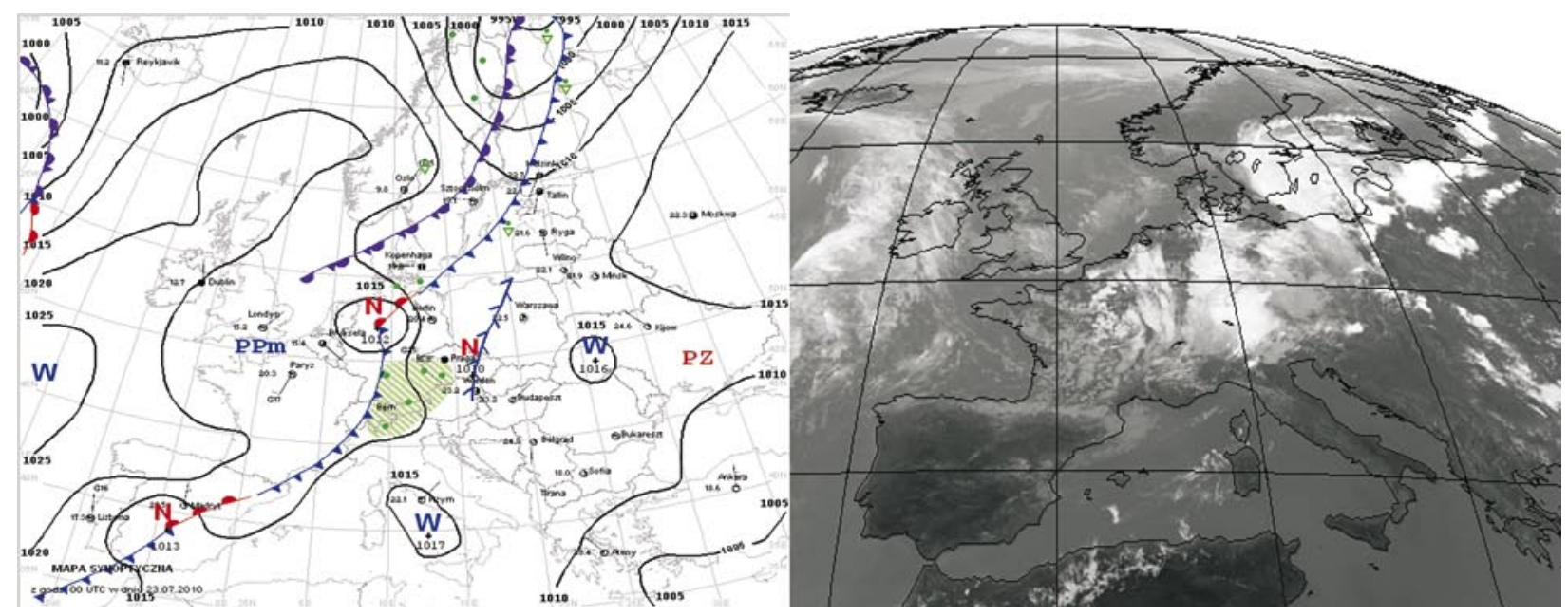

Fig. 19. Satellite photograph MSG2 (Ir 8.7 at 12.45 UTC) and synoptic map (at 0.00 UTC), taken on 23rd July 2010.

$\mathrm{m} / \mathrm{s}$ (at 16.00). The value of water vapour pressure remained high throughout the day, too, leading to a fall in sensible temperature.

The daily courses of individual meteorological elements described above are the result of the synoptic situation existing over the area of Central Europe (Fig. 19). At night, Poland was under the influence of a low-pressure trough in very warm tropical air. In turn, from the morning a cool atmospheric front was approaching the researched area. The cloud cover, initially small, grew to moderate and large. At noon, the cool atmospheric front followed by cool polar-maritime air was present over Łeba. Its action is shown by the abovementioned daily courses of selected meteorological elements: low solar radiation and a relatively low air temperature during the day (caused by considerable cloud cover), high air humidity (precipitation in the cool front zone) and relatively high wind speed.

\section{Day with sensible thermal conditions classified as "cold" (25th July)}

On 25th July, thermal conditions classified as "cold" were predominant. It was one of the coldest days of the researched period, and the values of radiation temperature (ET) and radiative-effective temperature (RET) were nearly identical (Fig. 20). From daybreak right up to 14.00, both RET and ET indicated sensible conditions from the cold range. However, from 15.00 onwards, conditions from the cool range were present.

The average daily temperature totalled $14.7^{\circ} \mathrm{C}$, and it was the lowest average from amongst all those noted during the researched period (Table 1). The minimal temperature on 25th July amounted to $13.5^{\circ} \mathrm{C}$, with the maximum being $17.2^{\circ} \mathrm{C}$ (Fig. 21). During the day, the air temperature - following a fall from approximately $16^{\circ} \mathrm{C}$, noted at midnight, to approximately $13.5^{\circ} \mathrm{C}$ at 3.00 - remained at the same level until 15.00. Next, the temperature rose rapidly to its daily maximum, and subsequently fell to a value of approx. $15^{\circ} \mathrm{C}$. At that time, sensible conditions were very strongly impacted by the wind. From the beginning of the day its speed reached $10 \mathrm{~m} / \mathrm{s}$ and gradually over the course of the day it fell to nearly complete silence at 23.00 . It is worth noting, however, that until 10.00 the wind speed exceeded $6 \mathrm{~m} / \mathrm{s}$, while until $12.00-5 \mathrm{~m} / \mathrm{s}$.

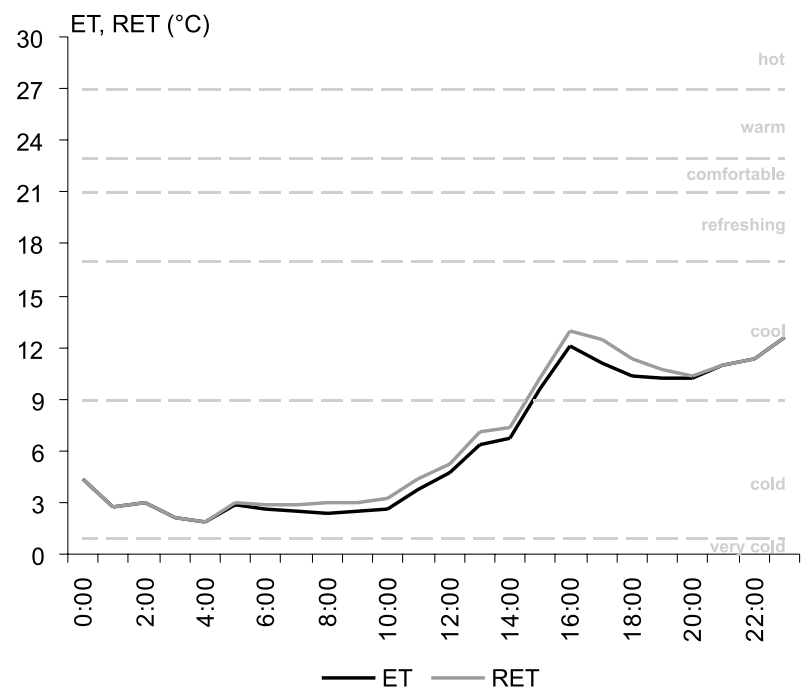

Fig. 20. Course of the daily effective temperature (ET) and radiative-effective temperature (RET) in Łeba on 25th July 2010. 


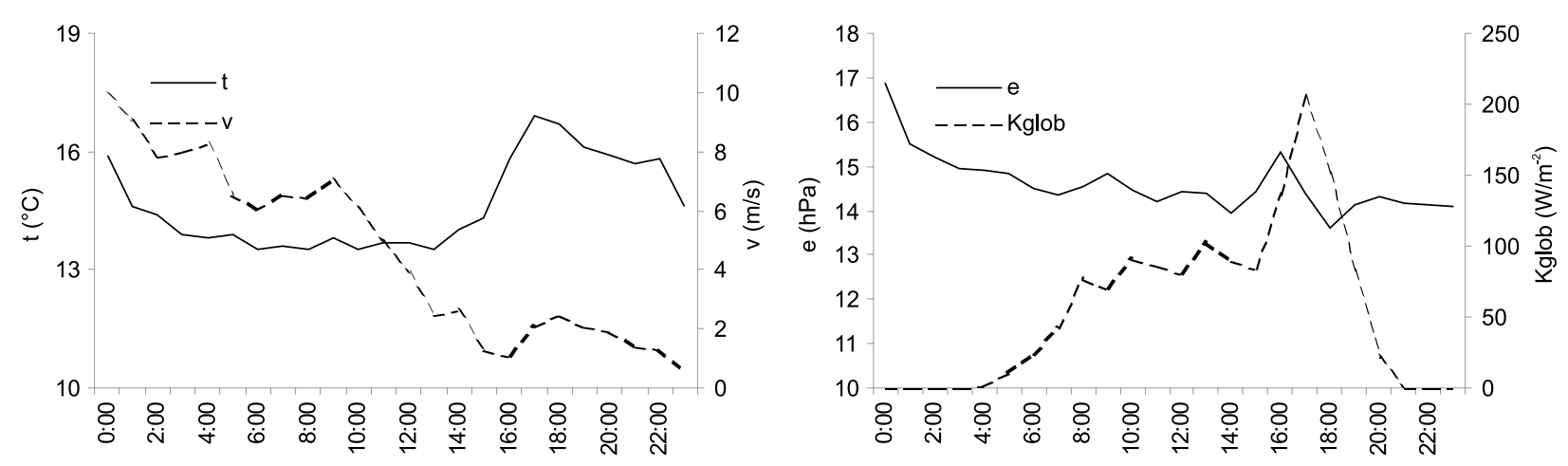

Fig. 21. Daily course of air temperature (t), wind speed (v), water vapour pressure (e) and total solar radiation (Kglob) in Łeba on 25th July 2010.
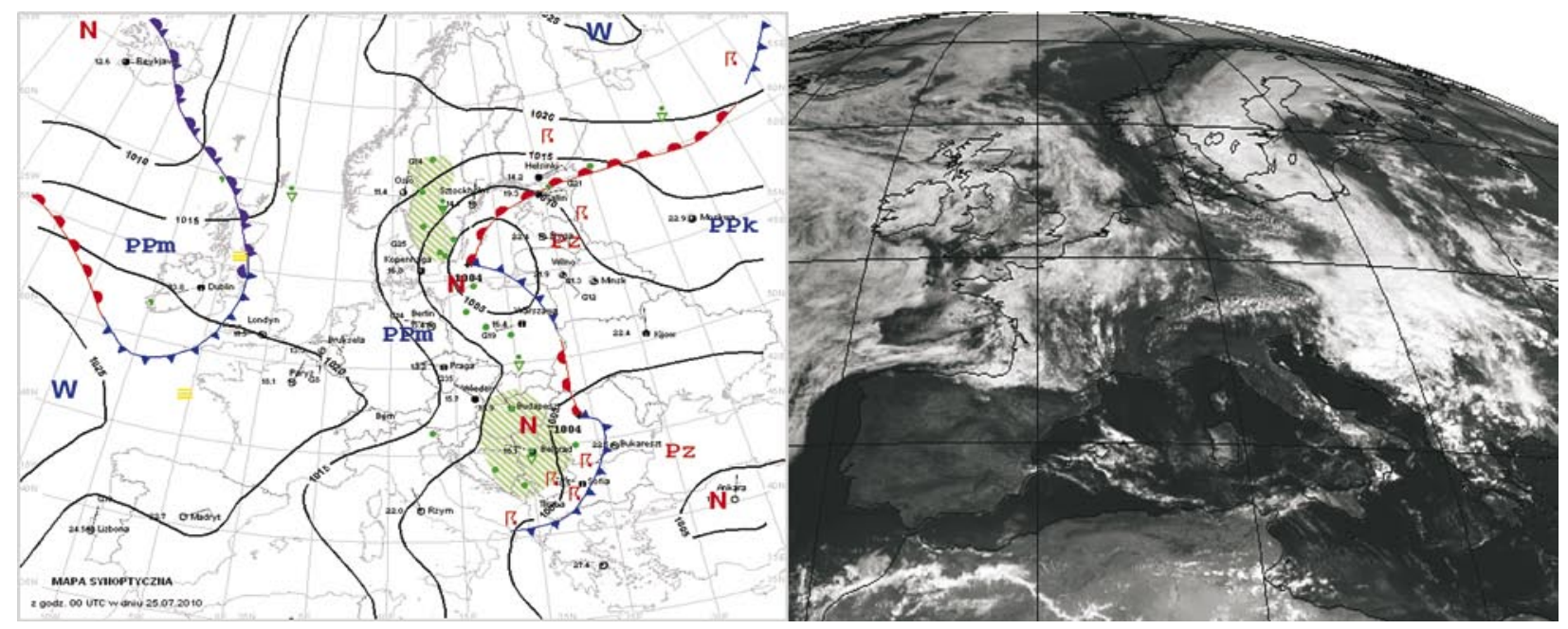

Fig. 22. Satellite photograph MSG2 (vis. at 10.00 UTC) and synoptic map (at 0.00 UTC), taken on 25th July 2010.

Values of total radiation noted during the researched day amounted to no more than $100 \mathrm{~W} /$ $\mathrm{m}^{2}$, with the exception of the value attained at 17.00 , when the daily maximum of $205 \mathrm{~W} / \mathrm{m}^{2}$ occurred (Fig. 21). In turn, values of water vapour pressure in general fell throughout the day, from approx. $17 \mathrm{hPa}$ at midnight to approx. $14 \mathrm{hPa}$ at 23.00. Only at $16.00 \mathrm{did}$ they rise to $15.3 \mathrm{hPa}$ (Fig. 21).

The daily course of the abovementioned elements was determined under conditions of a low approaching from the centre towards the southern Baltic. During the day, this low slowly shifted northwards. The cool front moving towards Poland was followed by a cooler mass of polarmaritime air (Fig. 22). The synoptic map shows the situation in the centre of the low in the area of Łeba at 0.00 . In turn, the satellite photograph taken a few hours later shows a low-pressure system together with a cloud cover system already shifted northwards (Fig. 22). This direction

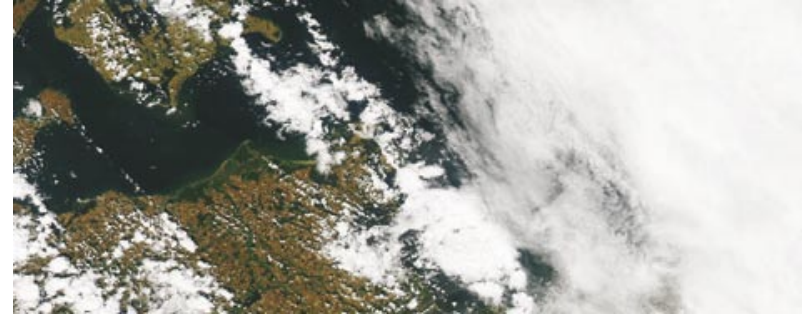

Fig. 23. Photograph from the Terra satellite (25.07.2010 at 12:05, by NASA).

and the relatively low speed of movement of the low resulted in long-term, considerable cloud cover and precipitation over the researched area. A higher resolution image taken at 12.05 shows the situation at the rear of the atmospheric front approaching the Polish border (Fig. 23), following the passage of which (at approx. at 17.00) the weather improved, and air temperature and the value of total radiation increased, leading to a concomitant increase in ET and RET (Fig. 21). 


\section{Day with sensible thermal conditions classified as "refreshing" (31st July)}

On 31st July between the hours of 7.00 and 17.00, RET indicated the presence of sensible

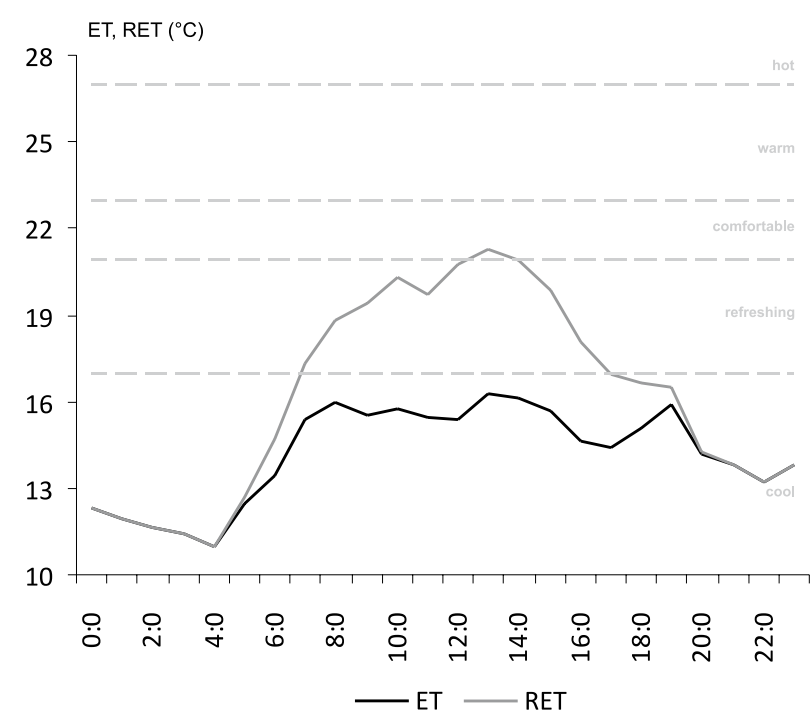

Fig. 24. Course of the daily effective temperature (ET) and radiative-effective temperature (RET) in Łeba on 31st July 2010.

thermal conditions classified as refreshing (Fig. 24). Exceptionally, at 13.00 conditions from the comfortable range were observed. In the remaining hours, the values of RET were classified as cool. On the other hand, the values of ET throughout the day indicated conditions from the cool range.

As regards the daily course of individual meteorological elements, one should note the considerably large values of total radiation (on this day, the daily average totalled $411 \mathrm{~W} / \mathrm{m}^{2}$ ). In such a situation one should expect high temperatures during the day, but in this case the average daily temperature amounted to $17.5^{\circ} \mathrm{C}$, while the maximum temperature was $21.3^{\circ} \mathrm{C}$. One of the reasons for this was the very cool night, which was brought about by the passage of an occluded atmospheric front on 30th July and by the influx of a mass of cooler polar-maritime air.

Another significant element shaping sensible conditions on this day was the wind speed. The highest values occurred in the afternoon, with the maximum of $2.6 \mathrm{~m} / \mathrm{s}$ being attained at 12.00 (Fig. 25). The highest values of water pressure vapour were also noted at the very same time (the maximum at 12.00 totalled $18 \mathrm{hPa}$ ).

On this day, the weather in Poland was determined by a low-gradient area of increased pressure in a relatively cool mass of polar-maritime air. The front zone ran eastwards, however this did not impact the conditions felt in Łeba (Fig. 26). During the first part of the day, the cloud cover was small; it subsequently developed to moderate, as can be clearly seen on the satellite photographs (Fig. 26 and 27).

\section{Day with sensible thermal conditions classified as "warm" (1st August)}

This day is classified as warm, for the radiative-effective temperature (RET) at 12.00 indicated a value from the warm range (Fig. 28). Similar sensibilities were noted on this day between 9.00 and 14.00. During this time, the values of effective temperature indicated conditions one range lower, i.e. comfortable. During the first part of the day, sensible conditions from the following ranges were also noted: cool (from 0.00 to 6.00), refreshing (approx. 7.00 according to RET and 7.00-9.00 according to ET), comfortable (at 8.00 according to RET, and 10-14 according to ET). In turn, from 15.00 until the end of the day both RET and ET
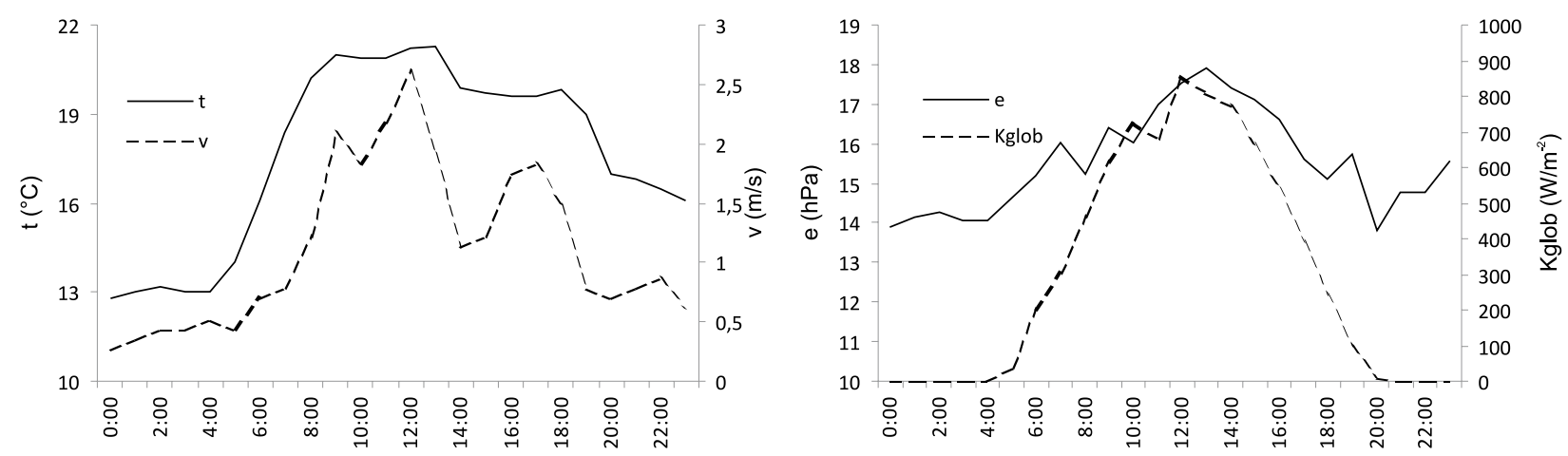

Fig. 25. Daily course of air temperature (t), wind speed (v), water vapour pressure (e) and total solar radiation (Kglob) in Łeba on 31st July 2010. 


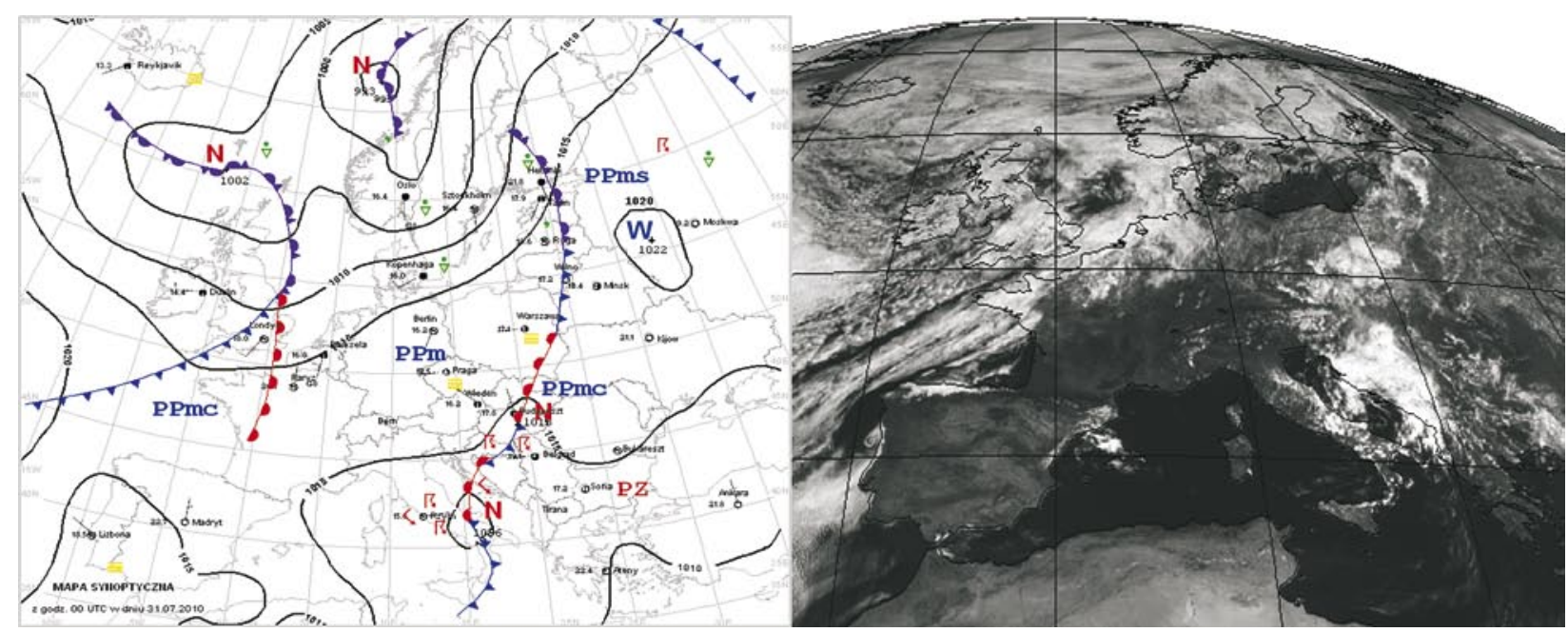

Fig. 26. Satellite photograph MSG2 (vis. at 11.00 UTC) and synoptic map (at 0.00 UTC), taken on 31st July 2010.

indicated refreshing conditions (with 19.00 being an exception, when according to RET the conditions were comfortable).

On this day, the value of thermal sensibility indices was influenced by the relatively large values of total radiation (the daily average totalled $242 \mathrm{~W} / \mathrm{m} 2)$, which impacted the high temperature values (with the maximum at 14.00 being $28.4^{\circ} \mathrm{C}$ ). A significant role in determining the thermal sensibility was also played by the wind and air humidity (Fig. 29). The wind speed from daybreak until 14.00 was under $1 \mathrm{~m} / \mathrm{s}$, and for this reason it did not hinder the increase in sensible temperature. However, between 15.00 and 17.00 the wind speed increased considerably, resulting in a fall in sensible temperature. What is more, from 15.00 there occurred a considerable increase in air humidity, from $12.5 \mathrm{hPa}$ at 13.00 to more than $18 \mathrm{hPa}$ during the period 15-19.00. An additional analysis of the wind direction showed that at that time the wind, hitherto blowing from the southern sector, started to blow from a northeasterly direction, bringing with it humid and cooler maritime air, which considerably modified the humidity and temperature of air. This clearly impacted the sensible temperature - the RET fell by two ranges, from warm to refreshing (Fig. 28).

The synoptic situation on this day is presented in figure 30. Poland was under the influence of a low-gradient area of increased pressure and a warm and humid mass of polar-maritime air. During the day, this caused an increase in cloud cover and fleeting precipitation and increased wind speed. The synoptic map shows the warm

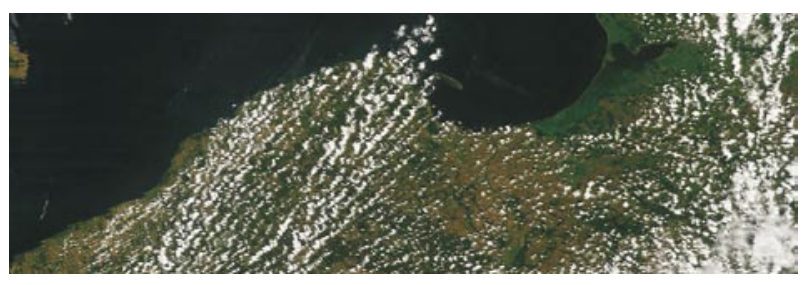

Fig. 27. Photograph from the Terra satellite (31.07.2010 at 9:40, by NASA).

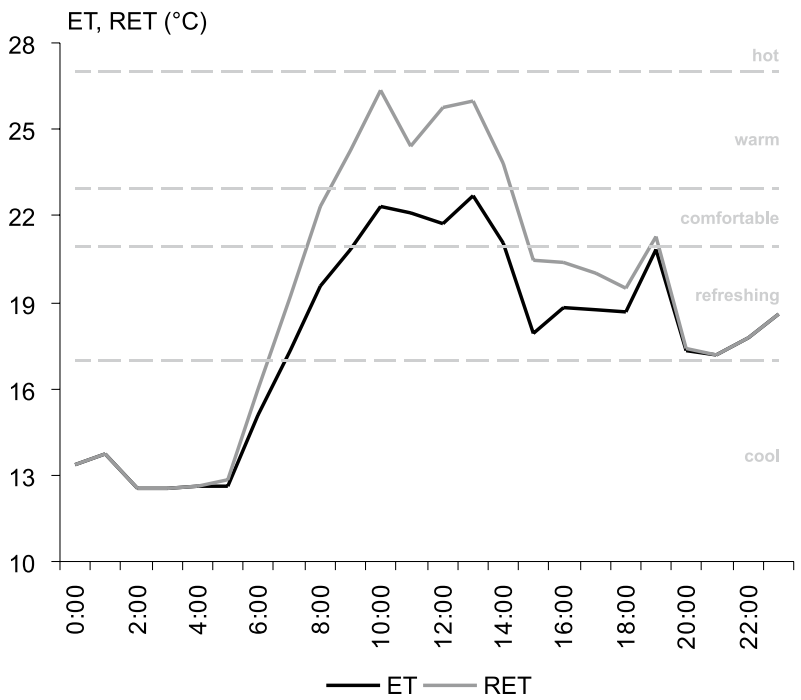

Fig. 28. Course of the daily effective temperature (ET) and radiative-effective temperature (RET) in Łeba on 1st August 2010.

atmospheric front west of Poland, which during the day moved over the researched area. The satellite photograph taken at 11.00 UTC shows this front moved westwards in relation to the synoptic map (Fig. 30), whereas another photograph, 


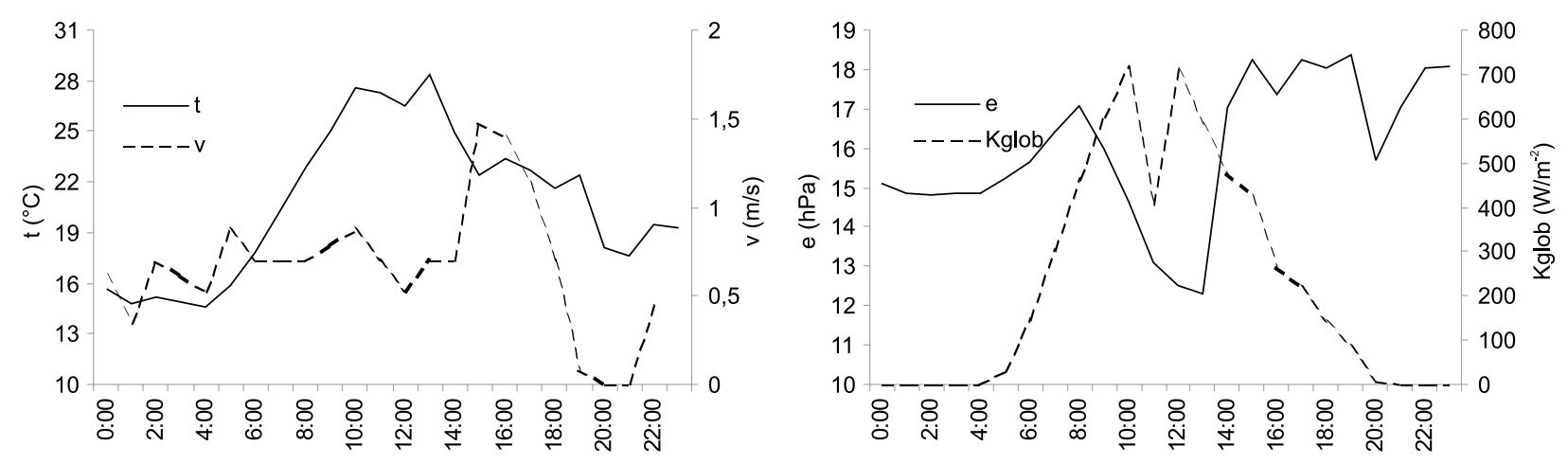

Fig. 29. Daily course of air temperature (t), wind speed (v), water vapour pressure (e) and total solar radiation (Kglob) in Łeba on 1st August 2010.

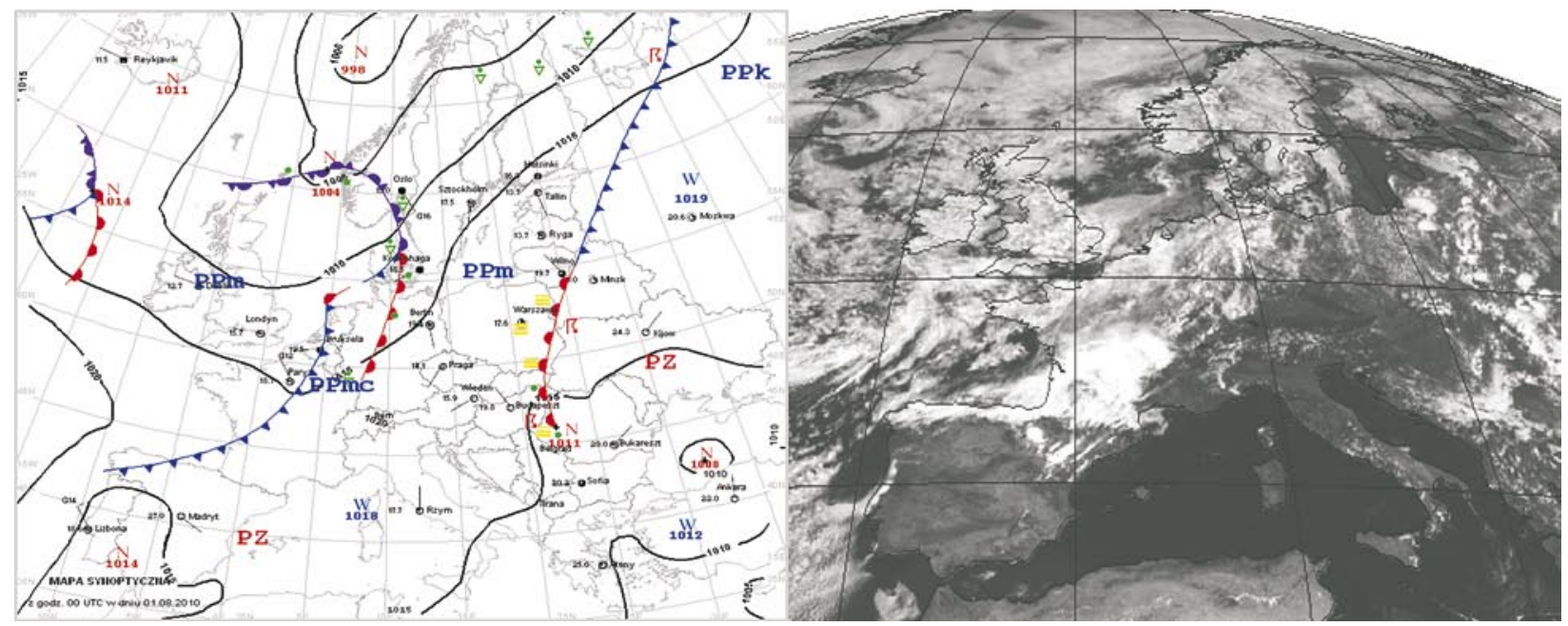

Fig. 30. Satellite photograph MSG2 (vis. at 11.00 UTC) and synoptic map (at 0.00 UTC), taken on 1st August 2010.

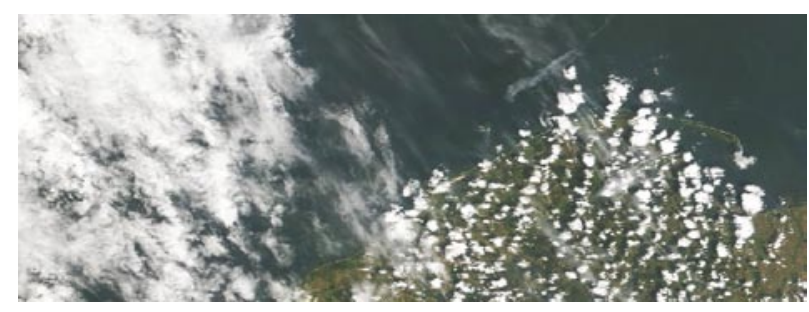

Fig. 31. Satellite photograph taken from the Terra satellite (01.08.2010 at 12:10, by NASA).

taken with a high resolution, shows the frontal part of the warm front cloud cover system (Fig. 31). Over Łeba, we can see high cirrus clouds transforming into cirrocumulus clouds, which point to the imminent appearance of the warm front, and also low cumulus clouds created as a result of thermal convection. The strong convection of air on that day between 15.00 and 16.00 caused the aforementioned local change in wind direction and an increase in its speed, thus leading to a fall in temperature and increase in water vapour pressure (Fig. 29).

\section{Conclusions}

Synoptic conditions impact the types of weather that are determined by meteorological elements such as air temperature and humidity, influx of solar radiation, and wind speed. The above elements are modified by local conditions. The sum of these factors impacts the development of the thermal sensibilities of people.

During the researched period, highly diverse sensible conditions were present. This was caused by the diversity of synoptic situations and local factors. The feeling of thermal conditions connected with heat stress occurred during high-pressure weather, with a considerable influx of total solar radiation and low wind speeds. As it turned out, the direction of influx of air masses is a very significant element. The analysis has shown that in the event of the presence of tropical air, the radiative-effective temperature attained the highest ranges of the adopted scale 
(Mikhailov's). On the other hand, in the presence of highs and cooler masses of polar-maritime air, the sensible conditions attained the comfortable (20.07) and refreshing (31.07) ranges. The coolest and most variable conditions occurred in the area of activity of the low-pressure system and atmospheric fronts. In these instances thermal feelings of cold were noted - on 23 rd July, the radiativeeffective temperature indicated cool, while on 25 th July - cold. The passage of an atmospheric front, additionally connected with a change in contrasting air masses (an example of 13th July, when tropical air was replaced with polar-maritime air), is one of the most stressful situations for the human body. Thermal feelings of hot changed on this day over a short time to the cool range.

Bioclimatic studies adopt the value of bioclimatic indices from the midday measurement point as representative for the entire day. The present study, which takes into consideration the daily course of indices (ET and RET), confirmed the correctness of this concept, for in the analysed instances the values of indices from the southern area fitted into the same ranges of the sensibility scale as the majority of values during a given day.

Local circulation may considerably modify sensible temperatures. This is clearly shown by the situation of 11th July and 1st August, when a change in wind direction (from the southern sector to the northern sector) led to an influx of cooler and more humid maritime air, thus causing a significant fall in the sensible temperature.

The values of effective temperature (ET) during the day with radiation weather indicate the lowest ranges of sensibility of the thermal condition. On the adopted scale, this is usually the range one level lower than that indicated by the radiative-effective temperature (RET). The radiative-effective temperature is a decidedly better index for assessing thermal conditions at the Łeba Sandbar, as it additionally takes into consideration the total values of solar radiation.

\section{References}

Bednorz E. \& Kolendowicz L., 2010. Daily course of the soil temperature in summer in chosen ecosystems of Słowiński National Park, northern Poland. Quaestiones Geographicae 29/1: 5-12.

BŁAŻEJCZYK K., 2004. Bioklimatyczne uwarunkowania rekreacji i turystyki w Polsce. Pr. Geogr. IGiPZ PAN 192: 291 s.

Freitas C.R. de, 2003. Tourism climatology: evaluating environmental information for decision making and business planning in the recreation and tourism sector. Int. J. Biometeorol. 48: 45-54.

GregorczuK M. \& LeśKo R., 1970. Temperatura efektywna i radiacyjno-efektywna na obszarze Polski. Przegl. Geofiz. XV (XXIII), 4: 339-349.

KRAWCZYK B., 1975. Bioklimat uzdrowiska Iwonicz. In: T. Kozłowska-Szczęsna (ed.), Problemy bioklimatologii uzdrowiskowej. Dok. Geogr. 3-4.

KrawczyK B., 1991. Próba typologii bioklimatu Polski na podstawie temperatury radiacyjno-efektywnej. Przegl. Geogr. LXIII, 1-2: : 43-55.

KoZŁoWSKA-SZCZĘSNA T., BŁażEJCZYK K. \& KRAWCZYK B., 1997. Bioklimatologia człowieka. Metody i ich zastosowanie w badaniach bioklimatu Polski. Monografie IGiPZ PAN 1.

LeŚKO R. \& GREGORCZUK M., 1968. Kształtowanie się komfortu klimatycznego w sezonie kąpielowym nad polskim Bałtykiem. Przegl. Geofiz. XIII (XXI), 3.

MARCINIAK K., 1974. Zastosowanie temperatur radiacyjnoefektywnych do oceny warunków bioklimatycznych Krynicy Morskiej. Zesz. Nauk. Ut, Nauki MatematycznoPrzyrodnicze, seria II, 63. 